\title{
GEOLOGIA E LITOGEOQUIMICA DO BATÓLITO ITAOCA, SUL DO ESTADO DE SÃO PAULO
}

\author{
GEOLOGY AND LITOGEOCHEMISTRY OF THE ITAOCA BATHOLITH, SOUTH OF SÃO \\ PAULO STATE
}

\author{
Jonas Menezes ZENEROㅜㅗ, Otávio Augusto Ruiz Paccola VIEIRA ${ }^{\mathbf{1}}$, Antonio Misson \\ GODOY ${ }^{2}$ \\ ${ }^{1}$ Pós-Graduação em Geociências e Meio Ambiente - Universidade Estadual Paulista. \\ Email: jonaszenero@gmail.com, otaviovieirageo@gmail.com \\ ${ }^{2}$ Departamento de Petrologia e Metalogenia - IGCE- UNESP- Universidade Estadual Paulista. Av. 24-A, 1.515. Rio Claro -SP. \\ Email: antonio.godoy@unesp.br

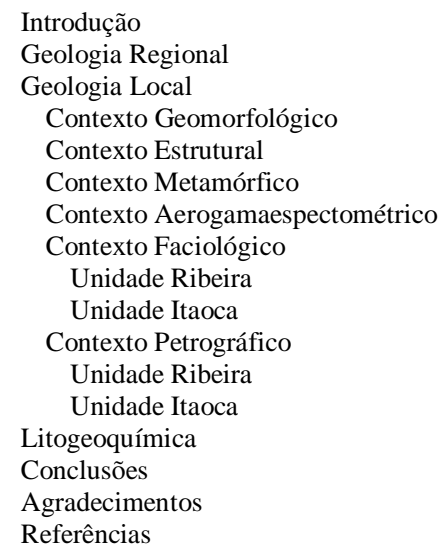

RESUMO - O Batólito Itaoca constitui um corpo intrusivo de forma circular, de $200 \mathrm{Km}^{2}$, localizado no limite sul entre os estados de São Paulo e o Paraná, na Folha Topográfica de Apiaí. Está associado a Província Mantiqueira Central e correlacionado a evolução neoproterozoica do Terreno Apiaí. As rochas encaixantes são constituídas pela sequência metavulcanossedimentar do Grupo Lajeado pertencente ao Supergrupo Açungui, além de apresentar no entorno do corpo magmático e nos teto-pendentes, rochas em fácies epidoto hornfels até piroxênio hornfels, além de mineralogias hidratadas superimpostas associadas a Zona de Cisalhamento Ribeira. As rochas do batólito foram divididas em duas unidades, denominadas de Itaoca e Ribeira, a primeira apresenta cor cinza e a segunda rósea. As duas unidades foram subdivididas em 6 fácies, sendo uma representada por uma associação de fácies indiferenciadas. Petrograficamente suas rochas constituem, basicamente, biotita-hornblenda-quartzo monzonito a monzogranito, holo- a leucocrático, porfirítico de granulação média a grossa, isotrópico a suborientado. A Unidade Itaoca é constituída de rochas menos evoluídas (quartzo monzonitos) e que, possivelmente, se trata de um pulso magmático primário frente a Unidade Ribeira, mais diferenciada (monzogranitos). As rochas granitoides apresentam caráter cálcio alcalino, peraluminoso, do tipo I cordilheirano, sin a tardi colisional de ambiente de arco magmático e geradas pela fusão de rochas da crosta inferior.

Palavras-chave: Itaoca; Granitos; Geologia; Litogeoquímica.

\begin{abstract}
The Itaoca Batholith constitutes an intrusive circular shape body, of $200 \mathrm{~km} 2$, located in the south limit between the São Paulo and Paraná states, in the Apiaí Topographic Map. It is associated with the Central Mantiqueira Province and correlated with the Apiaí Terrain neoproterozoic evolution. The embedding rocks are constituted by the Lajeado Group's metavolcanicsedimentary sequence belonging to the Açungui Supergroup, besides presenting in the surrounding of the magmatic body and in the ceilingpendants, rocks in epidote to pyroxene hornfels facies, in addition to superimposed hydrated mineralogies associated with the Ribeira Shear Zone. The batholith rocks were divided into two units, named Itaoca and Ribeira, the first one gray color and the second pink. The two units were subdivided into 6 facies, one represented by an undifferentiated facies association. Petrographically, its rocks basically constitute biotite-hornblende-quartz monzonite to monzogranite, holo- to leucocratic, porphyritic of medium to coarse granulation, isotropic to suboriented. The Itaoca Unit is made up of less evolved rocks (quartz monzonite) and, possibly, it is a primary magmatic pulse compared to the Ribeira Unit, which is more differentiated (monzogranite). These granitoid rocks have a calcium alkaline, peraluminous character, I cordilleran type, syn- to late collisional of a magmatic arc environment and generated by the fusion of lower crust rocks.
\end{abstract}

Keywords: Itaoca; Granites; Geology; Lithogeochemistry.

\section{INTRODUÇÃO}

O Batólito Granitoide Itaoca está situado na porção central da Folha Topográfica de Apiaí (Carta SG-22-X-B-V-1), na escala 1:50.000, do
Instituto Brasileiro de Geografia e Estatística entre as coordenadas limites $24^{\circ} 30^{\prime}$ Norte, $24^{\circ} 45^{\prime}$ Sul, $48^{\circ} 45^{\prime}$ Leste e $49^{\circ} 00^{\prime}$ oeste em 
relação a Greenwich. Encontra-se na região sul do estado de São Paulo, na divisa com o estado do Paraná e apresenta uma forma levemente ovalada na direção NE-SW, constituindo em uma área superior a $200 \mathrm{Km}^{2}$. Corresponde a uma grande depressão topográfica com altitudes médias inferiores a $150 \mathrm{~m}$, porém nas suas bordas as altitudes são acima de $700 \mathrm{~m}$.

Regionalmente, insere-se na Província Mantiqueira (Almeida \& Hasui, 1967, 1981; Hasui \& Oliveira, 1984; Heilbron et al., 2004), na Província Mantiqueira Central (Heilbron et al., 2004), na faixa sul do Cinturão Ribeira (Almeida et al.,1977; Cordani et al., 1973; Hasui et al., 1978; Hasui, 2010, 2012), na região sul do Cinturão de Dobramentos Sudeste (Cordani et al., 2000) e na região centro-sul da Faixa ou Cinturão Ribeira de Hasui \& Oliveira (1984).

O Cinturão Ribeira é caracterizado pelo Terreno Apiaí (Hasui, 2010, 2012) que é separado por zonas de cisalhamento transcorrentes destrais que compartimentam a região em grandes blocos tectônicos (Campanha, 1991, 2002; Campanha \& Sadowski, 1999; Heilbron et al., 2004; Faleiros, 2008; Faleiros et al., 2010, 2011; Santos et al., 2015, Campanha et al., 1987, 2008, 2015).

O Terreno Apiaí consiste em sequências supracrustais de baixo a médio grau metamórfico, designadas como Grupo Açungui (Almeida, 1957; Petri \& Suguio, 1969; Fiori, 1990; Campanha, 1991; Campanha \& Sadowski, 1999) e, posteriormente proposto, como Supergrupo Açungui (Campanha, 1991; Campanha \& Sadowski, 1999) (Figura 1). São rochas de idade mesoproterozoica a ediacarana definidas por Tassinari et al. (1990) e Fiori $(1992,1994)$ onde teve a divisão estratigráfica para a região proposta em três unidades litotectônicas principais, denominadas de Grupos Votuverava, Formação Água Clara e Grupo Lajeado (Figura 1).

As principais rochas no entorno do batólito envolvem o Grupo Lajeado (Campanha et al., 1985, 1986; Faleiros et al., 2012), reconhecidas em campo nas formações Betari, Bairro da Serra, Água Suja, Mina de Furnas, Serra da Boa Vista, Mármore de Apiaí, Passa Vinte, Gorutuba.

$\mathrm{O}$ presente trabalho pretende avaliar os aspectos evolutivos e petrogenéticos das rochas neoproterozoicas do Batólito Itaoca e apresentar os dados resultantes da investigação geológica e faciológica, estrutural, geofísica e geoquímica da área geográfica do batólito, além da compreensão geológica-tectônica deste magmatismo, inserido no contexto e arranjo geotectônico regional do Terreno Apiaí e associado a evolução da Zona de Cisalhamento Ribeira.

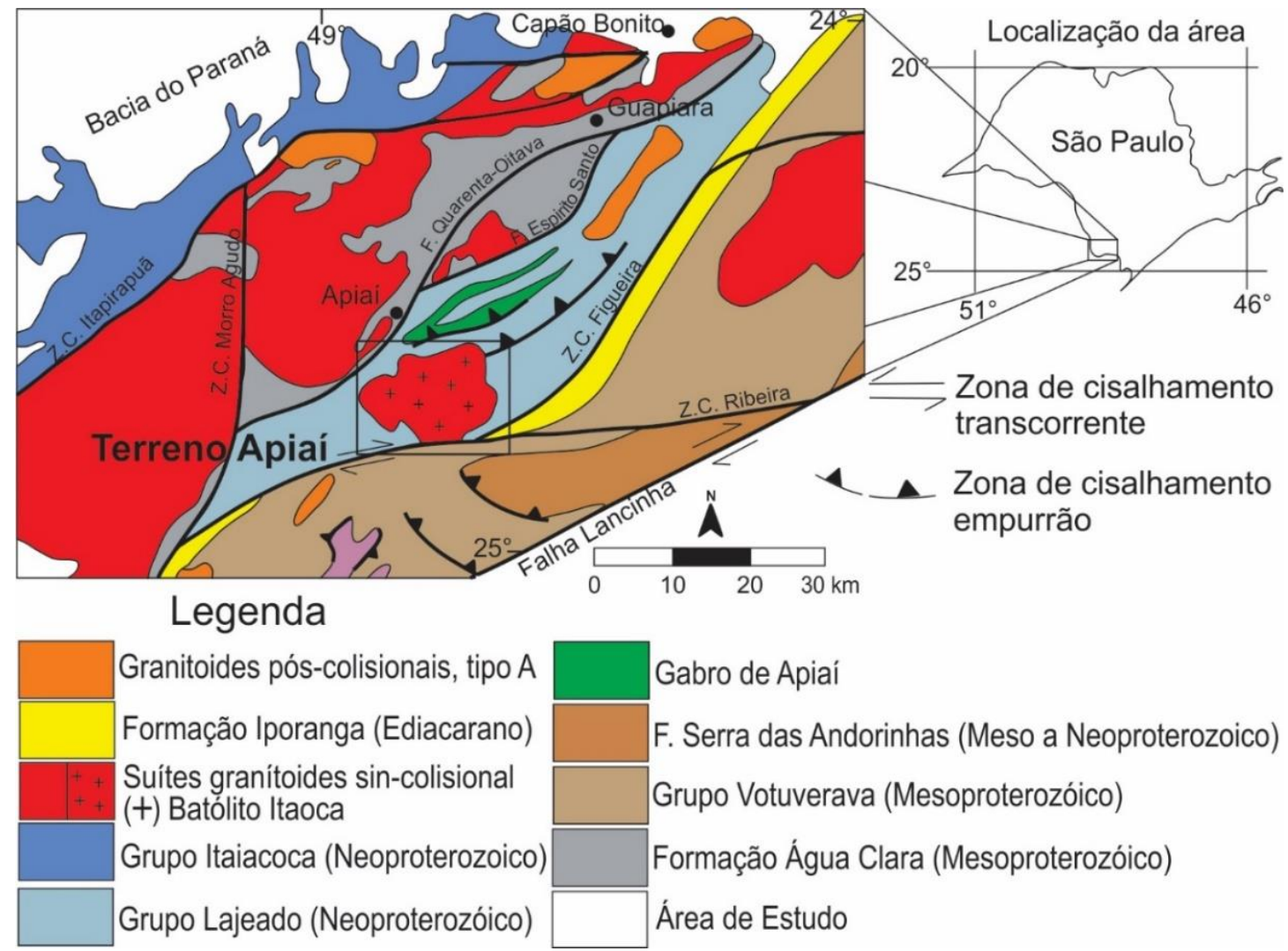

Figura 1 - Principais litologias e estruturas do Terreno Apiaí. O Batólito Itaoca está destacado. Adaptado de Campanha et al. (2015). 


\section{GEOLOGIA REGIONAL}

A região do batólito granitoide já encontra-se definida nos mapas geológicos do Estado de São Paulo, do Instituto Geográfico e Geológico, em escala 1:1.000.000, dos anos de 1963 e 1974, e no mapa geológico de integrações do estado de São Paulo em escala 1: 500.000, elaborado pelo Instituto de Pesquisa Tecnológica - IPT (Bistrichi et al., 1981; Almeida et al., 1981; Hasui et al., 1981). Os mapas de integrações regionais da área devem-se a Campanha, (1991, 2002) e foram utilizados na elaboração do mapa em escala 1: 750.000, pela Companhia de Pesquisa de Recursos Minerais (Perrotta et al., 2005). A integração atualizada da região, deve-se ao Serviço Geológico do Brasil - CPRM em "Geologia e Recursos Minerais da Folha Apiaí-SG.22-X-B-V", em escala de 1:50.000 (Faleiros et al., 2012).

Os trabalhos que abordam as rochas graníticas do Batólito Itaoca, na tentativa de associar e correlacionar a sua evolução com as diversas sínteses regionais, devem-se, inicialmente, a Melcher \& Johnson (1956) e, posteriormente, a Melfi et al. (1965) e Melcher (1965) na iniciativa pioneira de levantar geologicamente esta parte da área investigada, visando o conhecimento das formações pré-cambrianas e suas possibilidades minerais. Trabalhos específicos sobre as rochas graníticas da região devem-se também a Fuck et al. (1971).

O primeiro mapeamento geológico da área foi executado pela PROTEC - Projetos Técnicos e Obras de Engenharia Ltda., para o Departamento Nacional da Produção Mineral, denominado de "Projeto Ribeira" e, deve-se a sua divulgação a Melcher et al. (1971a) "Geologia das Rochas Précambrianas do Vale do Rio Ribeira de Iguape”. A síntese da evolução geológica correspondente da área deste projeto deve-se a Melcher et al. (1973) em "Geologia e petrologia das rochas metamórficas e graníticas associadas do Vale do Rio Ribeira de Iguape, SP e PR". Diversas cartas geológicas foram divulgadas por membros do projeto, sendo que a carta geológica da Folha Apiaí, na escala $1: 100.000$, foi publicada por Melcher et al. (1971b) e denominada de "Geologia da Folha de Apiaí, SP e PR". Os principais projetos institucionais que envolvem estudo da área na década de 80, restringem a Algarte et al. (1973), no trabalho de pesquisa mineral realizado em 1972/1974, "Projeto Sudeste do estado de São Paulo", pelo convênio Departamento Nacional de
Pesquisa Mineral (DNPM)/Companhia de Pesquisa de Recursos Minerais (CPRM) em escala 1:10.000, em que retomou os trabalhos na Folha de Apiaí entre outras áreas.

Morgental et al. (1975), pelo convênio DNPM/CPRM, apresentam no "Projeto Sudelpa" dados geológicos da Folha Araçaíba e Morgental et al. (1978) descrevem a geologia e geoquímica destes conjuntos de granitoides no projeto "Projeto Geoquímica no Vale da Ribeira".

Hasui et al. (1978), no trabalho de integração e sistematização das rochas granitoides do estado de São Paulo, propõe para o estado dois grandes conjuntos de rochas granitoides, sendo o Batólito Itaoca classificado como sintectônicos do tipo semelhante a Fácies Cantareira e do subtipo 5 Varejão, similar ao tipo Sin a Tardi-Tectônicos (tipo porfiroide) de Melcher et al. (1973) e dos granitóides cálcio-alcalinos sin a tardi-orogênicos de Janasi \& Ulbrich (1991)

As pesquisas pelo DNPM/CPRM culminaram no projeto "Projeto integração e detalhe geológico no Vale do Ribeira" de Silva et al. (1981) e divulgação dos mapas geológicos de 14 folhas topográficas em escala 1:100.000, entre as quais está a Folha de Apiaí (Silva et al., 1981).

Informações adicionais sobre o pré-cambriano da região do Ribeira para os seus recursos minerais são também encontradas em projetos executados nas escalas 1:50.000 e 1:25.000, que envolveram mapeamentos da região de Itaoca, com objetivos voltados a metalogênese.

No decorrer dos anos de 80 a 90, as rochas do Batólito Itaoca foram enumeradas em diversos projetos de pesquisa, pelo IPT, para atividades de prospecção e exploração mineral, devido as ocorrências minerais identificadas de $\mathrm{W}, \mathrm{Mo}, \mathrm{Cu}$, $\mathrm{Au}$ e $\mathrm{F}$, associados as mineralizações nos escarnitos, as quais ocorrem na porção interna do granito, na forma de tetos pendentes e megaxenólitos, ou em seu entorno, nas rochas encaixantes.

Quanto a sua inserção e evolução da granitogênese paulista deve-se a Hasui et al. (1978), Vlach et al. (1990) e Janasi \& Ulbrich (1992). Trabalhos sobre a geologia, geoquímica e petrologia dos granitoides do Vale do Ribeira (Gomes et al., 1975 a; b; Wernick \& Gomes, 1974; 1977; Landim et al., 1974; Wernick, 1979; Boin et al. (1983) e recentemente Mello (1995) e Mello \& Bittencourt (1998). 
O Serviço Geológico do Brasil-CPRM apresenta em Faleiros et al. (2012) e Lopes et al. (2017) o levantamento atualizado das ocorrências minerais da região de Itaoca, além de trabalhos regionais da área por Cury et al. (2008) e Zanella et al. $(2014 ; 2015)$.

Trabalhos específicos dos aspectos da metalogênse da região devem-se inicialmente a Chiodi Filho et al. (1989) e, especificamente sobre os escarnitos, Ens (1990). A partir dos estudos pelo IPT, diversos trabalhos dos membros da equipe são divulgados (Mello et al., 1981; Mello \& Silva, 1984; Mello et al., 1985; Mello \& Bettencourt, 1998; Tassinari \& Mello, 1994). Estes trabalhos encontram-se integrados na tese de doutorado Mello (1995) e Mello \& Bettencourt (1998), permitindo uma visão ampla do batólito e o único trabalho com a descrição faciológica do corpo.

Mello et al. (1981) propõe a distribuição das rochas do Maciço Granítico de Itaoca na forma de um corpo circunscrito e de forma elíptica com eixo maior na direção E-W, intrusivo em rochas metassedimentares do Supergrupo Açungui e Subgrupo Lajeado. Sugere-se para o maciço uma origem polidiapiríca em razão da identificação de estruturas elípticas e circulares e distinguindo duas suítes, designadas de Suíte Granitoide Itaoca e Suíte Granitoide Saltinho. Nota-se que, atualmente, manteve-se o formato geral do corpo e a divisão em duas unidades de cor, definidas por Melcher et al (1973).

Mello et al. (1981) propõe, ainda, a ocorrência de litologias hornfélsicas em toda a extensão lateral ao corpo granítico, que apresentam variações de largura de até $500 \mathrm{~m}$ e, internamente, na forma de enclaves de tamanhos centimétricos a centenas de metros de rochas metassedimentares encaixantes, e que foram denominadas de Suítes Termometamórficas.

Mello (1995) propõe para o Granito Itaoca a subdivisão faciológica em oito fácies magmáticas: a fácies cinza 1, 2 e 3 e as fácies Rósea 1, 2, 3, 4 e 5. As Fácies Cinza 3 e a Fácies Rósea 5, com exposição restrita e balizada por falhas ou zonas de cisalhamento foram interpretadas como processos de alteração tardi a pós-magmáticos; e uma associação de fácies (as fácies Miloníticas), abrangente de tipos intrusivos deformados, aflorantes em toda a borda sul do batólito, desenvolvidos pela ação transcorrente do Lineamento Ribeira.

Trabalhos específicos geocronológicos identificados da área e consultados devem-se a Mello (1995), Tassinari \& Mello (1994), Tassinari et al. (1994) e Mello \& Bettencourt (1998) e com abordagem geocronológica e de paleomagnetismo a Salazar et al. (2008). Mello (1995), a partir de dados radiométrico em rocha total de rochas da Unidade Saltinho, apresenta para fácies Rósea 2, idade $\mathrm{Rb} / \mathrm{Sr}$ de $626 \pm 27 \mathrm{Ma}$ (R.I. = 0,710-0,711). Por outro lado, os dados radiométricos das mineralizações de fluorita em filões da Zona de Cisalhamento do Pavão, permitem especular sobre a idade do evento cisalhante que apresenta a idade da mineralização e do cisalhamento em $520 \pm 30$ Ma (Tassinari \& Mello 1994). Salazar et al. (2008) obtiveram idade U-Pb SHRIMP em zircão de 623 \pm 10 Ma para a Fácies Itaoca e que é interpretada como a idade de cristalização (Tabela 1).

Salazar et al. (2008), em trabalho de anisotropia de suscetibilidade magnética nas rochas do batólito, propõe um modelo de alojamento combinado com o evento compressivo que gerou foliação, dobras e falhas que compartimentaram o Grupo Lajeado e evoluiu para cisalhamentos transcorrentes destrais e, que a partir da mudança na orientação dos esforços, teria criado extensão local na junção entre as zonas de cisalhamento Ribeira e Quarenta Oitava, que propiciaram a intrusão ígnea.

Tabela 1 - Datações isotópicas das rochas do Batólito Itaoca.

\begin{tabular}{c|c|c|c|c}
\hline & $\begin{array}{c}\text { Fácies } \\
\text { Magmática }\end{array}$ & $\begin{array}{c}\text { Idades } \\
\text { U-Pb(Ma) SHRIMP }\end{array}$ & $\begin{array}{c}\text { Rb-Sr } \\
(\mathbf{M a})\end{array}$ & Autor \\
\hline \multirow{4}{*}{$\begin{array}{c}\text { Batólito } \\
\text { Granitoide } \\
\text { Itaoca }\end{array}$} & Unidade Itaoca Fácies Cinza 1 & & $692 \pm 27$ & Tassinari \& Mello (1994) \\
\cline { 2 - 5 } & Fluorita em zona cisalhamento & & $520 \pm 30$ & Tassinari \& Mello (1994) \\
\cline { 2 - 5 } & Unidade Saltinho Fácies Rósea 2 & & $626 \pm 27$ & Mello (1995) \\
\cline { 2 - 5 } & Unidade Itaoca Fácies Cinza 3 & & $588 \pm 51$ & Mello (1995) \\
\cline { 2 - 5 } & Fácies Itaoca & $623 \pm 10$ & & Salazar et al. (2008) \\
\hline
\end{tabular}

\section{GEOLOGIA LOCAL}

A configuração metamórfica, magmática e seguem um padrão estratigráfico e estrutural tectônica da área de estudo, de modo geral, regional neoproterozoico, cujo principal trend se 
associa à orientação NE-SW e, que são metassedimentar teve como base a distribuição interrompidas ou contornam a área do Batólito litoestratigráfica proposta por Campanha et al. Itaoca. A organização da sequência $(1985,1986)$ e Faleiros et al. (2012) (Figura 2).
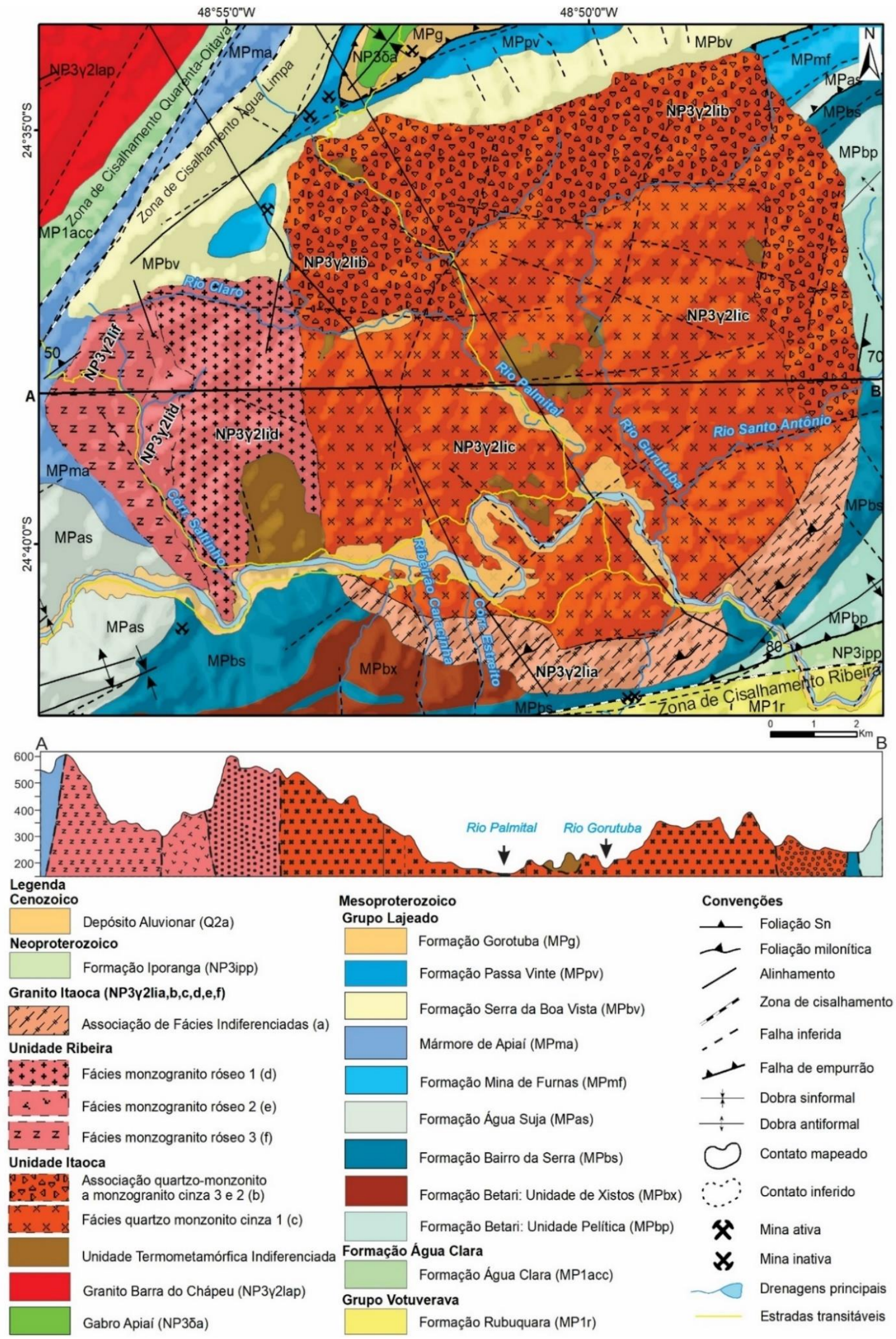

Figura 2 - Mapa geológico simplificado da região do Batólito Itaoca. 
A unidade mais antiga, meso- a neoproterozoico, é representada por rochas metassedimentares de baixo grau metamórfico, correlacionadas ao Supergrupo Açunguí, do Grupo Votuverava, Formação Água Clara e pela sequência Grupo Lajeado, seguidos das rochas ígneas, as básicas do Gabro Apiaí e as ácidas do Granito Apiaí e do Batólito Itaoca e, ainda, de maneira menos significativa, ocorrem intrusões máficas a ultramáficas, relacionadas as intrusões do Arco de Ponta Grossa, como diabásios e lamprófiros e os depósitos aluvionares de idade Cenozoica

No domínio das rochas encaixantes metassedimentares, serão descritas as rochas que se encontram em contato com os litotipos do Batólito Itaoca e, portanto, restringido às rochas metassedimentares do Grupo Lajeado. O Grupo Lajeado, observados a partir das formações em contato com as rochas ígneas: Betari, Bairro da Serra, Água Suja, Mina de Furnas, Serra da Boa Vista, Mármore Apiaí e Passa Vinte, além da Gorotuba restrita a norte do corpo ígneo. Este conjunto de rochas são representadas, na área, por uma gama de rochas diferenciadas, como mármore, rochas calciossilicatadas, filito, xisto, quartzito e metabasíto (Figura 2).
As rochas graníticas neoproterozoicas identificadas do Batólito Itaoca, representam o principal escopo dos estudos e serão descritas e correlacionadas aos termos descritos por Mello (1995).

\section{Contexto Geomorfológico}

A área aflorante do Batólito Granitoide Itaoca, superior a $200 \mathrm{Km}^{2}$, está posicionada dentro Província da Serrania Ribeira. A região central do corpo é caracterizada por uma área arrasada e topograficamente rebaixada que corresponde a uma depressão topográfica com altitudes médias de 140 a $300 \mathrm{~m}$, porém nas suas bordas as altitudes atingem 700 a $1000 \mathrm{~m}$ e passam a predominar escarpas formadas por grandes espigões digitados, lineares e subparalelos (Figura 3).

Localmente, áreas acidentadas e íngremes favorecem a formação de áreas mais dissecadas e erodidas, com inúmeras exposições das litologias na forma de grandes matacões e lajedos, parcialmente encobertos. Nas planícies de inundação do Rio Ribeira de Iguape, principalmente no seu afluente, o Córrego Guarda Mão, afloram inúmeros blocos de tamanhos variados distribuído intensamente ao longo de drenagens.

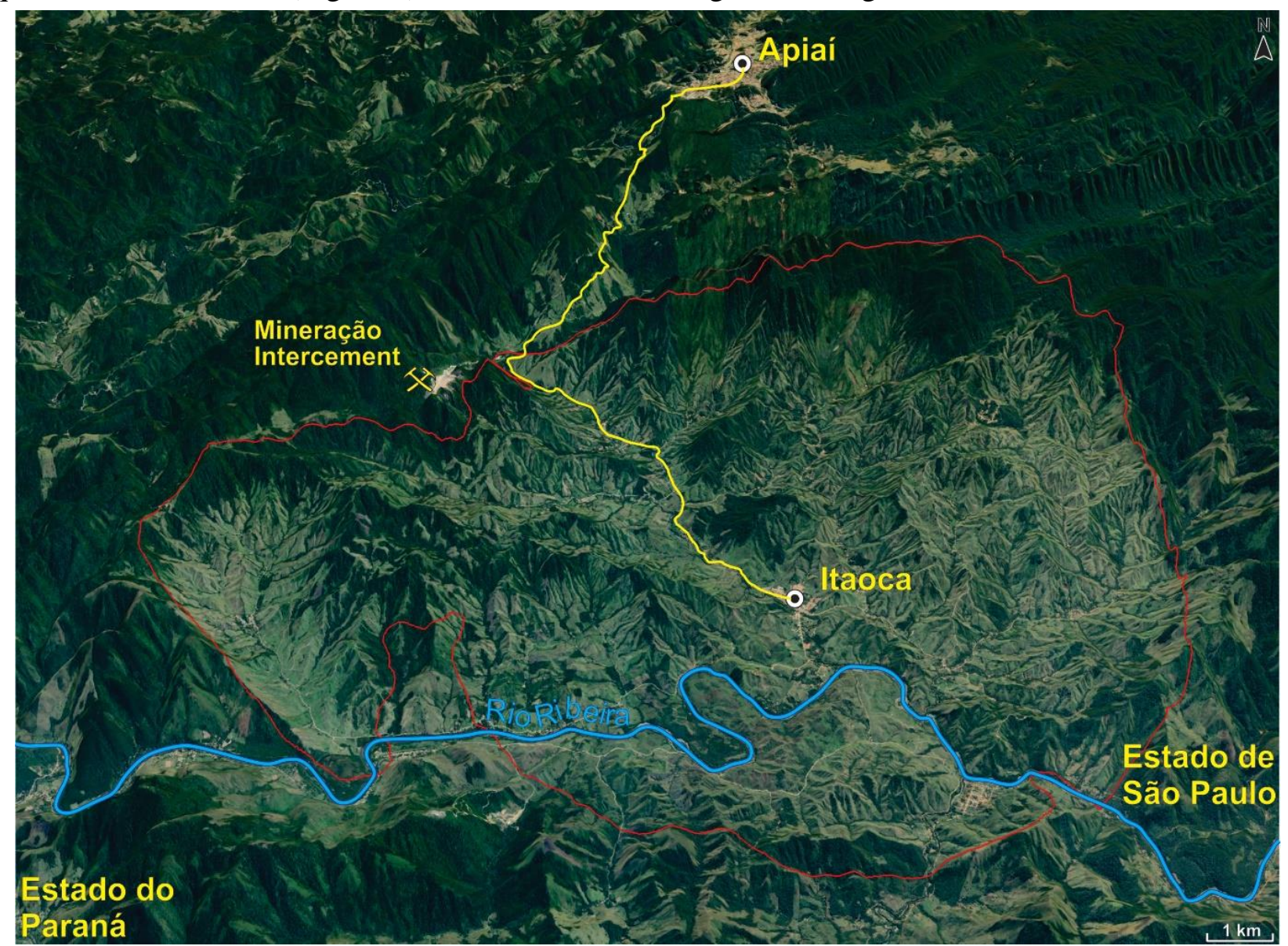

Figura 3. Limite das rochas do batólito Granitoide Itaoca em imagem do modelo digital de terreno SRTM. 


\section{Contexto Estrutural}

O mapa geológico das rochas do Batólito Itaoca, apresentado na figura 2, mostra os contatos com formato controlado e alongado NESW, segundo ramificações da Zona de Cisalhamento Ribeira e Quarenta Oitava. As rochas do Supergrupo Açungui são caracterizadas por uma evolução estrutural do tipo polifásica, evidenciada pelo registro principal de três fases deformacionais. As estruturas primárias são bastante frequentes, predominando o acamamento gradacional reliquiar $\mathrm{S}_{0}$, mas devido aos intensos processos de transposição por deformação milonítica regionais, nas áreas mais deformadas, passam a um bandamento tectônico imposto pelo cisalhamento.

As deformações progressivas tangenciais $\mathrm{D}_{1} \mathrm{e}$ $\mathrm{D}_{2}$ encontram-se associadas ao início do processo colisional, com formação de dobras da fase $\mathrm{D}_{1}$, isoclinais a recumbentes com foliação planoaxial $S_{1}$, de baixo ângulo e direção principal NE$\mathrm{SE}$, paralela à subparalela $\mathrm{a} \mathrm{S}_{0} \mathrm{e}$, de atitude média N50E/30SE. Visualizada apenas localmente e, muitas vezes, transposta por foliações posteriores.

A fase $D_{2}$ é definida por redobramentos assimétricos gerando uma clivagem ardosiana ou de crenulação $S_{2}$, de maior penetratividade na área, com atitude média de N60E/50SE e está ligada às zonas de cavalgamento presente. $\mathrm{O}$ ângulo de mergulho pode variar de baixo a médio, mas com rumo de mergulho diferente ao longo da área, representando os flancos de sinformal e antiformal da fase $\mathrm{D}_{3}$. A fase $\mathrm{S}_{2}$ é a mais importante no rearranjo tectônico, responsável pelo desenho dos dobramentos regionais, que invariavelmente são inversos ou recumbentes.

Localmente ocorrem as duas foliações $S_{1}$ e $S_{2}$, nas regiões de charneira, no entanto, quando paralelizadas, nos flancos das dobras, apenas a foliação $S_{2}$ é preservada.

A granitogênese brasiliana sin-colisionais do Batólito Itaoca, associa-se à uma tectônica dúctil tardi $\mathrm{D}_{2}$ com emplacement das rochas graníticas e a imposição de uma fraca foliação $S_{2}$, vista principalmente na reorientação dos minerais máficos (biotita e hornblenda) e, a geração de porfiroblastos controlado pelos planos axiais da clivagem de crenulação da fase $S_{2}$.

$A$ fase $D_{3}$ de caráter dúctil-rúptil a rúptil define a foliação $S_{3}$ de alto ângulo, com direção principal NE-SW e caindo ora para SE ou NW, além de caráter retrometamórfico para a área. É definida pela formação de dobras suaves a abertas (sinformais e antiformais) e sanfonadas de eixo sub-horizontal, com uma tênue clivagem subvertical, com plano axial de atitude N80E/80SE, que evolui gradativamente e localmente para falhas direcionais, ambas paralelas ao "trend" regional NE-SW a E-W, paralelos à direção da Zona de Cisalhamento Ribeira. A foliação $S_{3}$ é penetrativa nas zonas de cisalhamento caracterizando-se como uma foliação milonítica, com a geração de filonitos com acamamento tectônico que oblitera as demais estruturas reliquiares. Os granitóides apresentam, quando expostas, um caráter fracamente milonítico a blastomilonítico nas bordas.

Portanto, as estruturas rúpteis são caracterizadas por zonas miloníticas principalmente no contato sul e, localmente em porção interna. Sobrepostas a essas zonas miloníticas e de falhas são definidos processos cataclásticos, como um processo evolutivo final da deformação, em níveis mais rasos, ocasionando a geração de pseudotaquilitos, o que acaba por dificultar sua classificação, principalmente quando ocorre mudanças nas cores dos feldspatos, propiciado pela movimentação de fluídos metassomáticos.

A tectônica fanerozoica, fase mais recente observada na área, é uma tectônica mais tardia de caráter predominantemente rúptil de direção majoritária NW-SE, que interceptam as rochas do batólito. São grandes alinhamentos associados ao "relaxamento", posterior a fase final deformacional, os quais, são posteriormente intrudidos, aproveitando essa direção principal, por rochas básicas, correlacionadas a Formação Serra Geral.

\section{Contexto Metamórfico}

Os tipos de metamorfismo desenvolvidos na área são caracterizados por um evento metamórfico $\mathbf{M}_{1}$ associado as fases deformacionais regionais e é considerado do tipo dinamotermal (orogênico) progressivo, da série Barroviana ( $\mathrm{P} / \mathrm{T}$ moderadas), em fácies xistoverde, na zona da biotita e/ou granada e, localmente, para fácies anfibolito.

$\mathrm{O}$ evento metamórfico $\mathrm{M}_{1}$ é o mais representativo ao longo da área e é principalmente observado sobre as unidades metassedimentares do Supergrupo Açungui que 
são constituídas por uma associação de metassedimentos caracterizada dominantemente por filito, metarritmito, metassiltito, metarenito e xisto, além de metarcóseo, metamarga, mármore e anfibolito. $\mathrm{O}$ auge do metamorfismo foi contemporâneo à fase de deformação $\mathrm{D}_{2}$, evidenciado pelo crescimento de granada como um dos minerais formadores da clivagem $\mathrm{S}_{2}$.

A paragênese mais comum é quartzo + mica branca + clorita + biotita em metapelitos, eventualmente acompanhada da biotita + muscovita + granada em $\mathbf{M}_{2}$. Em relação às rochas calciossilicáticas, encontra-se a paragênese actinolita + biotita + epidoto.

$\mathrm{O}$ emplacement ígneo gera recristalização e desenvolvimento de minerais de contato sobre os do metamorfismo regional, alcançando a fácies albita e piroxênio hornfels $\left(\mathrm{M}_{2}\right)$. As paragêneses são marcadas pela presença de biotita + feldspato potássico + andaluzita desenvolvida principalmente na forma de megaporfiroblastos e poiquiloblásticos, orientados segundo a foliação $\mathrm{S}_{2}$. A paragênese andaluzita + feldspato potássico indicam relação P-T da ordem de 650700 oC e pressões superiores a 2 Kbar.

Ens (1990), em estudos dos escarnitos da área, constata que os tetos pendentes da parte central do batólito foram inicialmente afetados por metamorfismo de contato de caráter isoquímico, em temperatura superior a $650{ }^{\circ} \mathrm{C}$. Posteriormente, com a progressiva consolidação magmática e atingida a saturação em $\mathrm{H}_{2} \mathrm{O}$ na massa ígnea, soluções aquosas iniciaram os processos metassomáticos responsáveis pela formação dos escarnitos, e pelas paragêneses retrógradas.

A Formação Minas de Furnas na Mineração Intercement, possibilita a identificação de processo localizado de metamorfismo hidráulico, a partir de concentração de fluidos quentes ricos em carbonatos e de $\mathrm{CO}_{2}$.

As auréolas de metamorfismo termal apresentam-se parcialmente preservadas em função do maior ou menor grau de deformação imposto pela foliação $S_{3}$ nas zonas miloníticas, nos contatos destes maciços, ou devido a intensidade das transformações minerais retrometamórficas impostas pelo metamorfismo, que ocorre tanto nas paragêneses de contato como nas regionais.

Localmente, o metamorfismo dinâmico $\mathrm{M}_{3}$ é intenso e vinculado à foliação milonítica, principalmente da Zona de Cisalhamento
Ribeira, com desenvolvimento de filonitos com acamamento tectônico que oblitera estruturas reliquiares nas zonas de cisalhamento do final da fase $\mathrm{D}_{3}$. $\mathrm{O}$ metamorfismo $\mathrm{M}_{4}$ de caráter retrometamórfico superpõe ao conjunto minerais das rochas, desestabilizando as paragêneses anteriores, para condições de fácies xisto-verde baixa.

\section{Contexto Aerogamaespectométrico}

Pela emissão dos raios gama, quando ajustado para uso na geologia, é possível realizar a medição dos elementos $\mathrm{K}, \mathrm{U}$ e $\mathrm{Th}$ em rochas, sedimentos e solos, por meio da detecção da radiação gama emitida pelo decaimento natural desses elementos presentes nos minerais. Os terrenos onde afloram rochas graníticas tendem a obter boas respostas gamaespectométricas, visto que, essas rochas apresentam teores relevantes dos elementos K, Th e U.

$\mathrm{Na}$ figura 4 os mapas produzidos a partir dos dados aerogamaespectométricos disponibilizados pelo Serviço Geológico do Brasil (CPRM), em que foram inseridos os limites das unidades no presente trabalho afim de ilustrar e caracterizar a relação entre as respectivas respostas das rochas por elementos analisados.

O mapa de contagem de $\mathrm{K}$ (Figura 4A) reproduz a melhor equivalência com os contatos externos das rochas do batólito, expressando valores mais altos das intensidades relativas de $\mathrm{K}$, reflexo de rochas graníticas que apresentam teores maiores em biotita e feldspato potássico.

Os mapas de $\mathrm{Th}$ e $\mathrm{U}$ apresentam contraste observado pela resposta do elemento U (Figura 4B), particularmente nas mesmas áreas que apresentam boa resposta do elemento Th (Figura 4C), além de apresentar inúmeras pequenas ocorrências com valores mais elevadas internamente nas rochas do batólito.

O mapa de contagem (CT) (Figura 4D) para $\mathrm{K}$, Th, U apresenta resultados muito bons na delimitação das rochas do batólito e acaba sendo uma resposta aos altos valores de potássio, como também marca a direção NW-SE de deformação interna no batólito, refletida nos sedimentos de aluvião depositados pelos principais corpos d'água e que ocupam esse alinhamento, além da boa resposta na delimitação das grandes unidades mapeadas (Itaoca e Ribeira).

\section{Contexto Faciológico}

A disposição e caracterização faciológica das rochas do batólito encontram-se na figura 2. A 
evolução petrogenética das rochas do batólito associam-se necessariamente a fase colisional de espessamento $\mathrm{D}_{1 / 2}$, apresentando registro de deformações de baixo ângulo. As zonas de fraqueza mais antiga, como as zonas de cisalhamentos transcorrentes Ribeira e Quarenta Oitava, com trend regional NE-SW, permitem a geração de estruturas do tipo pull-apart, que facilitam a ascensão e emplacement destes magmas, após o metamorfismo regional principal e, são rejuvenescidas até o fim do Ciclo Brasiliano, condicionando a sua forma final do batólito, levemente alongada, bem como afetando tardiamente suas bordas.
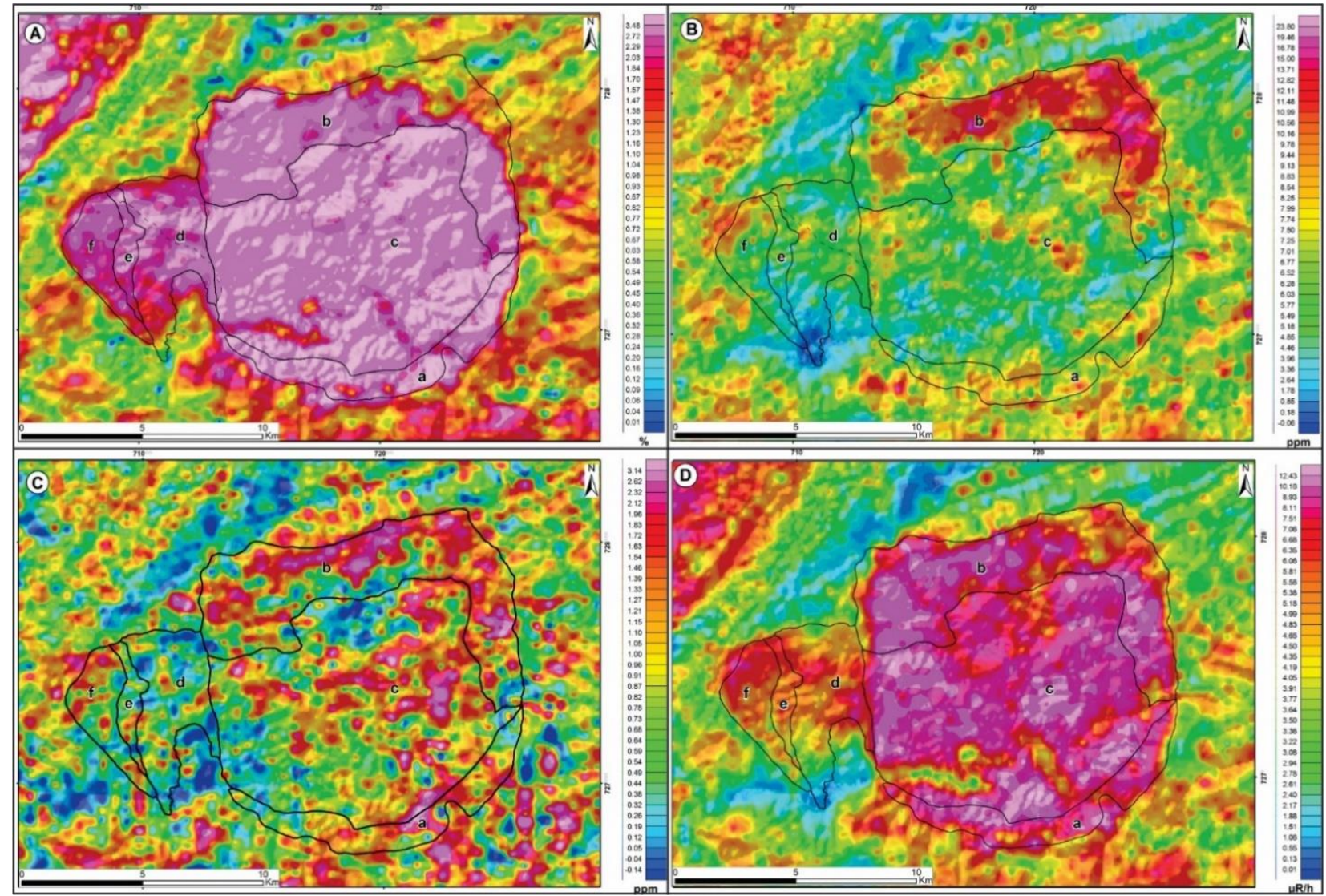

Figura 4 - Mapa Aerogamaespectométrico: A) Contagem de K; B) Contagem de Th; C) Contagem de U; C) Contagem total (CT) para K, Th e U a região das rochas do Batólito Itaoca.

$\mathrm{O}$ evento de cisalhamento discordante do trend regional (NW-SE) é de menor intensidade e apresenta, em alguns casos associado, movimentos horizontais, associado a deformação $\mathrm{S}_{3}$, que secciona internamente as rochas do batólito. Este sistema de falhamentos possivelmente expõe, dentro do maciço, corpos magmáticos de profundidade diferentes $\mathrm{e}$, portanto, apresentando-se atualmente em níveis erosionais distintos. Este arranjo contribuiria para explicar a distinção brusca das fácies granitoides, como também, a variação dos tipos e intensidade presentes de xenólitos das áreas contíguas.

A granitogênese das rochas do Batólito Itaoca é determinada por uma fase inicial, evidenciada por pequenos enclaves, com dimensões centimétricas, geralmente ovalados ou arredondados de autólitos de microgranodioritos, microdioritos e metagabro e enclaves microgranulares, além de enclaves surmicáceos e muito xenólitos das rochas encaixantes. Muitas vezes ocorrem schlieren micáceos resultantes de misturas de magmas e assimilações.

A fase principal na construção do batólito é responsável pela intrusão de grandes massas de quartzo monzonito a monzogranito de coloração cinza, a Unidade Itaoca - Cinza 1, em níveis epizonais a mesozonais, que fragmentaram e incorporaram as rochas das fases iniciais. Esta grande área corresponderia a parte central oriental, que remete a um bloco magmático com exposição de grande parte do nível superior, o teto do corpo magmático, onde, na sua parte mais rasa, pode ser visto pela distribuição de inúmeros tetos pendentes, além de ser caracterizada por uma maior homogeneidade de fácies, sendo dominantes o quartzo monzonito porfirítico cinza de matriz de granulação média a grossa. A fase final da intrusão principal é caracterizada por 
intrusões laterais que dominam a parte norte e nordeste do batólito de monzogranito mais diferenciados de coloração cinza, a Unidade Itaoca- Associação 2 e 3.

A fase final do batólito é marcada por impulsos magmáticos de coloração róseo mais diferenciados, constituídos por monzogranito na parte oeste do batólito, sugerindo que esta fração do corpo exposto evidencia um stock zonado das fácies de coloração rósea, visto pela distribuição das rochas da Unidades Ribeira e pelas fácies róseas 1,2 e 3 .

A colocação deste impulso magmático é tectonicamente controlada pelas direções de fraqueza, constituindo em uma tectônica de blocos mais tardia de caráter mais rúptil de direção NW-SE, que através de rejeitos com componentes horizontais e verticais, colocam lateralmente fácies dos granitoides de profundidades, variações texturais, estruturais e composicionais diferentes.

A fase tardia é marcada por intrusões de granitos equigranulares, aplitos e pegmatitos finais afetando todos os níveis expostos do complexo.

Lateralmente e internamente, nas regiões da cúpula do batólito, grande intensidade e variados tamanhos de xenólitos e teto pendentes das rochas encaixantes estão presentes, mineralizados ou não.

Os xenólitos e teto pendentes das rochas encaixantes chegam em alguns locais a anatexia e digestão desses metassedimentos pelíticos e químicos e, consequentemente, à geração, localizada de granito com composição e/ou texturas modificadas. No contato nordeste, norte e noroeste do complexo é mais frequente e preservada a auréola de metamorfismo de contato com dimensão de até centenas de metros. Localmente, eventos deformacionais da Zona de Cisalhamento Ribeira, no contato sul do batólito, obliteram parcial as estruturas e minerais formados no metamorfismo de contato, por um retrometamorfismo tardio.

As texturas que aparecem com maior frequência são as porfiríticas, mas termos equi- a inequigranulares, aplíticos e pegmatóides também são comuns.

O índice de coloração destes litotipos é basicamente leucocrático com variedades desde holo- até melagranitóides.

O batólito compreende tipos petrográficos agrupados em associações de fácies segundo características geológicas semelhantes em 6 fácies e ou associações de fácies que apresentam variações composicionais quartzo monzonítica a monzogranítica.

Não incluindo os corpos localizados de dioritos a granodioritos. Foram devidamente mapeadas e classificadas: 2 unidades denominadas de Itaoca e Ribeira e uma Associação Indiferenciada e 6 subdivisões faciológicas para as rochas granitoides denominadas de fácies cinza 1,2 e 3, fácies rósea 1,2 e 3. Na escala de mapeamento e observado no mapa geológico da figura 2 as Fácies Cinza 3 e 2 foram agrupadas e denominadas de Associação Cinza 2 e 3, com destaque para a Associação Indiferenciada.

A tabela 2 apresenta as denominações de divisão litoestratigráfica das fácies do Batólito Itaoca utilizadas por Mello (1995) e Mello \& Bittencourt (1998), em comparação aos termos deste trabalho.

Tabela 2 - Sumário da nomenclatura das fácies das rochas do Batólito Itaoca.

\begin{tabular}{|c|c|c|c|c|c|}
\hline \multicolumn{3}{|c|}{ Mello (1995) / Mello \& Bittencourt (1998) } & \multicolumn{3}{|c|}{ Zenero } \\
\hline Unidade & Associação (As) & Fácies (F) & Unidade & Associação (As) & Fácies (F) \\
\hline Milonítica & As. F. Milonítica & & & Indiferenciada & \\
\hline \multirow{4}{*}{ Saltinho } & As. F. Rósea 3 & As. F. Rósea 3 & \multirow[t]{4}{*}{ Ribeira } & & \multirow[t]{2}{*}{ Monzogranito - Róseo 3} \\
\hline & As. F. Rósea 4 & As. F. Rósea 4 & & & \\
\hline & & F. Rósea 2 & & & Monzogranito - Róseo 2 \\
\hline & & F. Rósea 1 & & & Monzogranito - Róseo 1 \\
\hline \multirow{3}{*}{ Itaoca } & As. F. Cinza 1 & & \multirow[t]{3}{*}{ Itaoca } & \multirow{3}{*}{\begin{tabular}{|c|} 
Quartzo Monzonito \\
a Monzogranito \\
Cinza 1 e 2 \\
\end{tabular}} & Monzogranito - Cinza 3 \\
\hline & & F. Cinza 2 & & & $\begin{array}{c}\text { Quartzo Monzonito a } \\
\text { Monzogranito - Cinza } 2\end{array}$ \\
\hline & & & & & Quartzo Monzonito - Cinza 1 \\
\hline
\end{tabular}

\section{Unidade Itaoca}

A Fácies Quartzo Monzonito Cinza 1 (Figura 5A) compõem os tipos predominantes, correspondendo ao arcabouço do batólito e ocupa toda a porção central do granito, abrigando a região urbana do município de Itaoca, além dos principais tetos pendentes mineralizados da área.

A rocha corresponde a quartzo monzonito 
porfirítico bimodal com variações subordinadas para tipos hiatais, de coloração cinza a levemente rosado. Estrutura predominantemente isotrópica, mas exibem localmente estruturas anisotrópicas, definidas desde uma discreta foliação dúctilrúptil até fortemente foliadas, de natureza milonítica. Nos termos miloníticos os minerais assumem formas alongadas, estiradas e exibem recristalização parcial e definem texturas do tipo argamassa, com domínios poligonais e domínios lepidoblásticos em função de estruturas intensamente foliadas. Estruturas de fluxo são pouco frequentes e estão representadas basicamente por bandas de enriquecimento em megacristais de microclínio.

Os fenocristais são de microclínio de cor branca em concentrações da ordem de 15 a $20 \%$. As dimensões dos fenocristais euedrais a subeudrais variam de 0,5 a $1,2 \mathrm{~cm}$. A matriz apresenta coloração cinza e composição quartzo monzodiorítica com textura inequigranular e tamanho médio, da ordem de 0,1 a $0,3 \mathrm{~cm}$. Observa-se com frequência a distribuição de veios aplíticos e pegmatóides de coloração branca de espessuras centimétricas a decimétricas, por vezes alaskíticos, além da intensa participação dos tetos pendentes na distribuição topográfica da fácies.

$\mathrm{Na}$ Associação Cinza 2 e 3 são identificadas as rochas referentes a Fácies Quartzo-Monzonito Cinza 2 e da Fácies Monzogranito Cinza 3, que não são diferenciadas no mapa, devido à proximidade composicionais, texturais e por se tratar da porção de maior dificuldade de mapeamento, com relevo muito acidentado e coberto por floresta nativa.

A Fácies Quartzo Monzonito a Monzogranito Cinza 2 (Figura 5B) encontra-se na região da borda norte a nordeste do batólito, fazendo contato com às rochas metassedimentares do Grupo Lajeado, mais especificamente com às formações Betari, Bairro da Serra, Água Suja, Mina de Furnas e Boa Vista.

A rocha corresponde a quartzo monzonito a monzogranito porfirítico, coloração acinzentada clara, leucocrática, isotrópica e textura porfirítica serial a hiatal de matriz com granulação média a grossa. Os fenocristais apresentam predominantemente dimensão serial e localmente assumem aspecto hiatal, de tamanho sempre menor que $2 \mathrm{~cm}$, mas ocasionalmente com variedades de feldspato potássico tamanho inferior a $4 \mathrm{~cm}$.
A Fácies de Monzogranito Cinza 3 (Figura 5C) localiza-se na também na região norte e nordeste do batólito. A rocha corresponde a um monzogranito porfirítico apresentando coloração acinzentada a rósea clara, mas permitindo a presença em situações localizadas, e mais intemperizada, de feldspato róseo, com variedades de holo- até melagranitoides. Apresenta estrutura isotrópica e textura porfirítica bimodal. Os fenocristais, numa proporção de 5 a $10 \%$ do total da rocha, compõem duas modas e variam de 0,5 a $1 \mathrm{~cm}$ e 1,5 a $2 \mathrm{~cm}$ em matriz de granulação média a grossa. Ainda, nas porções mais próximas ao contato com as rochas encaixantes, apresenta feições texturais mais finas devido a uma cristalização mais rápida na borda do maciço.

\section{Unidade Ribeira}

A Fácies Monzogranito Róseo 1 (Figura 5D) ocorre na porção extremo oeste do batólito em contato com rochas encaixantes metassedimentares. A fácies monzogranito róseo 1 é característica por apresentar, dentro da unidade das fácies róseas, a textura porfirítica composta pelos maiores fenocristais, os quais alcançam até 1,5 centímetros imersos em matriz equigranular com granulação grossa. Não apresenta orientação preferencial e com cerca de $10 \%$ de máficos.

A Fácies Monzogranitos Róseo 2 (Figura 5E) localiza-se na porção centro oeste do maciço, controlado por falhamentos secundários, associados à Zona de Cisalhamento Ribeira. São rochas de coloração rósea, leucocráticas, que apresentam trama sal e pimenta e textura inequigranular a levemente porfirítica com poucos fenocristais dispersos pela matriz de tamanho pequeno $(0,5 \mathrm{~cm})$.

Os fenocristais são róseos, dispersos em matriz também rósea, de granulação que varia de fina a média, isotrópica a sub-orientada (os máficos apresentam orientação), geralmente mostrando feições miloníticas e texturas porfiroclástica.

A Fácies Monzogranito Róseo 3 (Figura 5F) apresenta estrutura maciça, sub-orientada, com textura inequigranular a porfirítica, alotriomórfica e matriz equi- a inequigranular. $\mathrm{O}$ microclínio é róseo a levemente branco, com tamanhos relativamente pequenos $(0,5 \mathrm{a} 0,8 \mathrm{~cm})$. A matriz é leucocrática rósea equi- a inequigranular, de granulação média, com cristais da ordem dos 0,2 a $0,5 \mathrm{~cm}$, composta por 
cristais máficos de biotita e hornblenda suborientados a isotrópicos.

A Associação de Fácies Indiferenciadas serão tratadas em uma gama de fácies encontradas no batólito que sofreu deformação, devido a movimentos de falhas, provavelmente relacionados ao final do alojamento $\mathrm{e}$ esfriamento do Batólito Itaoca. São representadas por rochas encontradas em locais de falhas, fundos de grandes vales e leitos de rios e córregos encaixados, além de zonas de cisalhamento associadas em seus entornos. A região sul-sudeste do batólito apresenta a maior área de superposição de deformações pela Zona de Cisalhamento Ribeira, com a maior gama de litotipos submetidas ao metamorfismo dinâmico e associado a processos de retrometamorfismo, exibindo granitoides foliados a gnáissicos protomiloníticos, miloníticos e blastomiloníticos e intensa alteração hidrotermal. Esta área é equivalente as fácies miloníticas de Mello (1995).

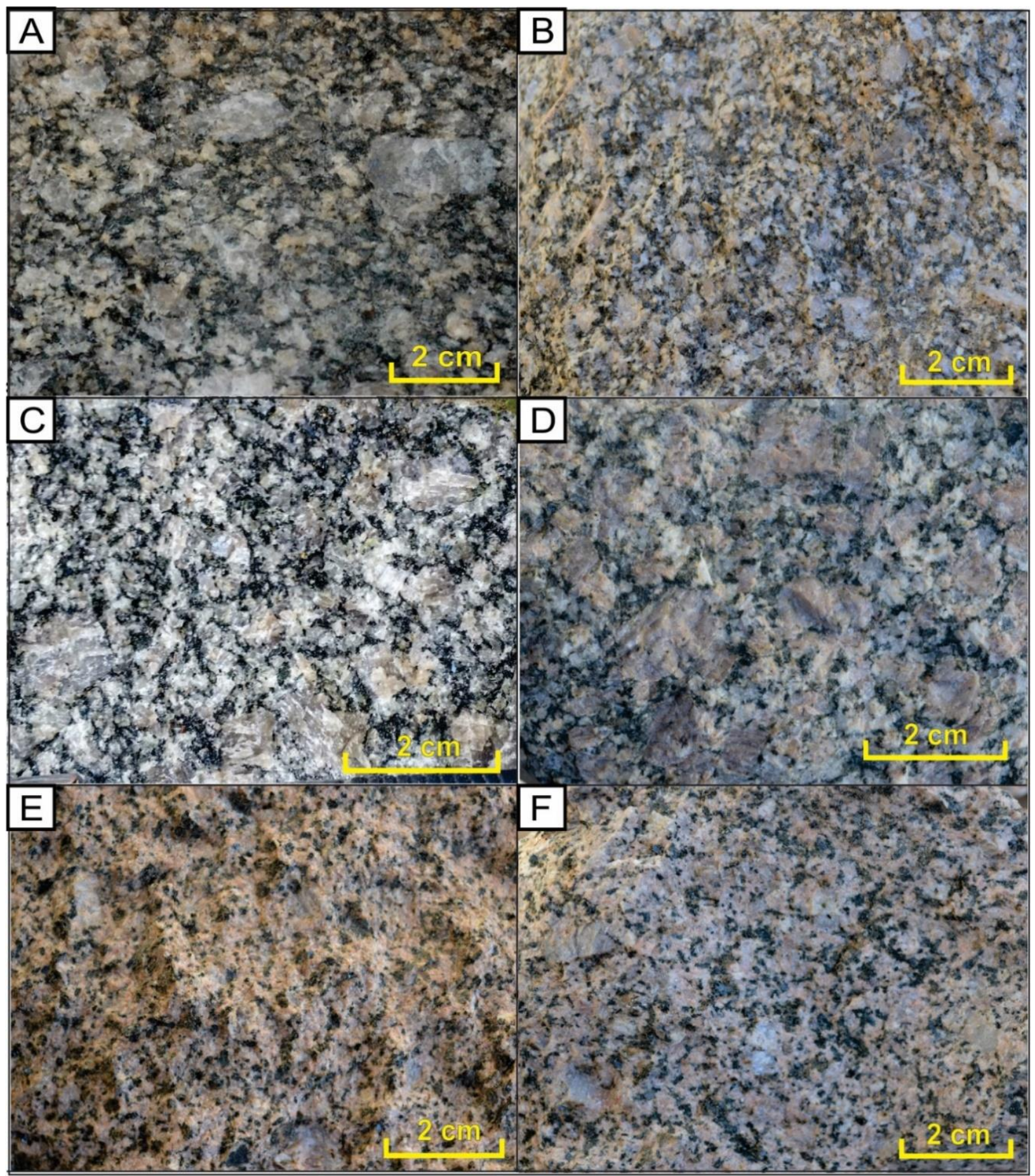

Figura 5 - A) Fácies Quartzo Monzonito Porfirítico Cinza 1 com fenocristais de FK; B) Fácies Quartzo Monzonito a Monzogranito Cinza Porfirítico 2 com fenocristais claros de FK em matriz média; C) Fácies Monzogranito Porfirítico Cinza 3; D) Fácies Monzogranito Porfirítico Róseo 1 anisotrópico; E) Fácies Monzogranito Róseo 2 inequigranular a levemente porfirítico levemente anisotrópico; F) Fácies Monzogranito Porfirítico Róseo 3 anisotrópico. 


\section{Contexto Petrográfico}

Os dados petrográficos obtidos para o grupo de amostras do Batólito Itaoca resultaram em uma mineralogia básica que compreendem como minerais félsicos o microclínio pertítico ou não, oligoclásio e/ou andesina, quartzo e como minerais máficos, biotita e hornblenda, ao lado de minerais acessórios como zircão, apatita, titanita, allanita e minerais opacos e minerais secundários são resultados principalmente de biotitização, saussuritização e caulinização, e correspondem à clorita, sericita, carbonatos, epidoto, biotita, hidróxidos de ferro e minerais opacos.

Raras são as turmalinas e as muscovitas secundárias que ocorrem em fácies com intenso processo de assimilação e/ou por processos metassomáticos, comum nas fácies tardias pegmatoides e áreas próximas a xenólitos.

Os dados oriundos da contagem modal de minerais félsicos foram lançados no diagrama QAP de Streckeisen (1976) (Figura 6) e são apresentados na tabela 3, com um sumário das principais características petrográficas das variedades das amostras e segundo a divisão das fácies proposta na figura 2 .

As diferentes fácies e ou associações descritas, baseiam-se principalmente em aspectos microscópicos e macroscópicos de: composição, textura, estrutura, coloração da rocha, cor dos feldspatos, tipos de máficos e índice de cor.



Figura 6 - Diagrama QAP com as médias das amostras do Batólito Itaoca.

Tabela 3 - Sumário petrográfico das associações e fácies granitoides do Batólito Itaoca.

\begin{tabular}{|c|c|c|c|c|c|c|c|}
\hline \multicolumn{8}{|c|}{ Batólito Itaoca } \\
\hline & \multicolumn{3}{|c|}{ Unidade Itaoca } & \multicolumn{3}{|c|}{ Unidade Ribeira } \\
\hline \multicolumn{2}{|c|}{ Fácies } & Fácies Cinza 1 & Fácies Cinza 2 & Fácies Cinza 3 & Fácies Rósea 1 & Fácies Rósea 2 & Fácies Rósea 3 \\
\hline \multicolumn{2}{|c|}{ Estrutura } & Isotrópica & Isotrópica & Isotrópica & Isotrópica & Anisotrópica & Anisotrópica \\
\hline \multicolumn{2}{|c|}{ Textura } & $\begin{array}{l}\text { Porfirítica } \\
\text { bimodal }\end{array}$ & $\begin{array}{l}\text { Porfirítica } \\
\text { serial }\end{array}$ & $\begin{array}{l}\text { Porfirítica } \\
\text { bimodal }\end{array}$ & $\begin{array}{l}\text { Porfirítica } \\
\text { serial }\end{array}$ & $\begin{array}{l}\text { Inequigranular } \\
\text { a porfirítica }\end{array}$ & $\begin{array}{l}\text { Porfirítica a } \\
\text { inequigranular }\end{array}$ \\
\hline \multicolumn{2}{|c|}{ Matriz } & $1-3 \mathrm{~mm}$ & $2-5 \mathrm{~mm}$ & $2-5 \mathrm{~mm}$ & $2-4 \mathrm{~mm}$ & $2-5 \mathrm{~mm}$ & $4-5 \mathrm{~mm}$ \\
\hline \multicolumn{2}{|c|}{ Fenocristal FK (mm) } & $5 / / 12$ & $5-6$ & $5-10 / / 15-20$ & 5 & $5-8$ & 15 \\
\hline \multicolumn{2}{|c|}{$\begin{array}{c}\text { Descrição } \\
\text { Fenocristal }\end{array}$} & $\begin{array}{l}\text { róseo a cinza } \\
(+/-20 \%) \mathrm{FK}\end{array}$ & $\begin{array}{l}\text { róseo a cinza } \\
(+/-15 \%) \mathrm{FK}\end{array}$ & $\begin{array}{c}\text { cinza } \\
(+/-18 \%) \mathrm{FK}\end{array}$ & $\begin{array}{c}\text { róseo } \\
(+/-20 \%) \mathrm{FK} .\end{array}$ & $\begin{array}{c}\text { róseo } \\
(+/-5 \%) \mathrm{FK} .\end{array}$ & $\begin{array}{c}\text { róseo } \\
(+/-8 \%) \mathrm{FK} .\end{array}$ \\
\hline \multicolumn{2}{|c|}{ Índice de cor (\%) } & Leucocrático & Leucocrático & Leucocrático & Leucocrático & Leucocrático & Leucocrático \\
\hline \multirow{3}{*}{$\begin{array}{l}\text { Minerais } \\
\text { Félsicos }\end{array}$} & Qtz & 18 & 21 & 23 & 25 & 24 & 26 \\
\hline & FK & 24 & 27 & 27 & 28 & 38 & 36 \\
\hline & Plag. & 345 & 43 & 40 & 40 & 30 & 29 \\
\hline \multirow{3}{*}{$\begin{array}{c}\text { Minerais } \\
\text { Fe-Mg }(\%)\end{array}$} & Anf. & 6 & 3 & 4 & 2 & 3 & 3 \\
\hline & Biot. & 7 & 6 & 6 & 5 & 5 & 6 \\
\hline & Total & 13 & 9 & 10 & 7 & 8 & 9 \\
\hline \multicolumn{2}{|c|}{$\begin{array}{l}\text { Minerais } \\
\text { Acessórios }\end{array}$} & $\begin{array}{l}\text { apatita, titanita } \\
\text { allanita, zircão, } \\
\text { minerais opacos }\end{array}$ & $\begin{array}{l}\text { apatita, titanita } \\
\text { allanita, zircão } \\
\text { magnetita. }\end{array}$ & $\begin{array}{c}\text { apatita, titanita } \\
\text { allanita, zircão } \\
\text { magnetita }\end{array}$ & $\begin{array}{l}\text { apatita, titanita } \\
\text { allanita, zircão } \\
\text { minerais opacos. }\end{array}$ & $\begin{array}{l}\text { apatita, titanita } \\
\text { allanita, zircão } \\
\text { minerais opacos. }\end{array}$ & $\begin{array}{l}\text { apatita, titanita } \\
\text { allanita, zircão } \\
\text { minerais opacos }\end{array}$ \\
\hline \multicolumn{2}{|c|}{$\begin{array}{l}\text { Minerais } \\
\text { Alteração }\end{array}$} & $\begin{array}{l}\text { sericita, epidoto } \\
\text { carbonato } \\
\text { clorita, biotita } \\
\text { minerais opacos }\end{array}$ & $\begin{array}{l}\text { sericita, epidoto } \\
\text { carbonato } \\
\text { clorita, biotita } \\
\text { minerais opacos }\end{array}$ & $\begin{array}{l}\text { sericita, epidoto } \\
\text { carbonato } \\
\text { clorita, biotita } \\
\text { minerais opacos }\end{array}$ & $\begin{array}{l}\text { sericita, epidoto } \\
\text { carbonato } \\
\text { clorita, biotita } \\
\text { minerais opacos }\end{array}$ & $\begin{array}{l}\text { sericita, epidoto } \\
\text { carbonato } \\
\text { clorita, biotita } \\
\text { minerais opacos }\end{array}$ & $\begin{array}{c}\text { sericita, epidoto } \\
\text { carbonato } \\
\text { clorita, biotita } \\
\text { minerais opacos }\end{array}$ \\
\hline \multicolumn{2}{|c|}{ Classificação } & $\begin{array}{l}\text { Biotita- } \\
\text { hornblenda- } \\
\text { quartzo } \\
\text { monzonito }\end{array}$ & $\begin{array}{l}\text { Biotita-quartzo } \\
\text { monzonito com } \\
\text { hornblenda }\end{array}$ & $\begin{array}{l}\text { Biotita- } \\
\text { monzogranito } \\
\text { com } \\
\text { hornblenda }\end{array}$ & $\begin{array}{l}\text { Biotita } \\
\text { monzogranito } \\
\text { com } \\
\text { hornblenda } \\
\end{array}$ & $\begin{array}{l}\text { Biotita } \\
\text { monzogranito } \\
\text { com } \\
\text { hornblenda }\end{array}$ & $\begin{array}{l}\text { Biotita } \\
\text { monzogranito } \\
\text { com } \\
\text { hornblenda }\end{array}$ \\
\hline
\end{tabular}




\section{Unidade Itaoca}

As fácies cinzas apresentam composição de quartzo monzonito para a fácies inicial e transicionando para monzogranito para a fácies final (Figura 6, Tabela 3), sugerindo uma evolução, a partir deste aumento progressivo de sílica, que as fácies iniciais vão se diferenciando para as fácies finais. Dominantemente, as fácies cinza apresentam texturais porfirítica bimodais a serial, com distribuição entre 20 a $15 \%$ de fenocristais de feldspato potássio (Tabela 3), representando mais de uma fase de cristalização mineral, imerso em matriz de granulação média a grossa, alotriomórfica à hipidiomórfica e de composição quartzo monzonito a monzogranito.

As mudanças composicionais ocorrem predominantemente por um crescente aumento em quartzo e de feldspato potássico nos litotipos, variações texturais de porcentagens de fenocristais e em relações a pequena variação de minerais máficos dominado por biotita $\mathrm{e}$ hornblenda.

O quartzo apresenta-se de duas formas, uma parcialmente corroída e a forma dominante intersticial definindo uma trama granítica (Figura 7A).

O oligoclásio/andesina apresenta textura mirmequítica e geralmente é intensamente zonado, representando um zoneamento rítmico, de microbandas mais cálcicas e sódicas. Esta variação composicional é evidenciada principalmente pelo grau distintos de saussuritização do zoneamento (Figura 7A). Muitas vezes, este zoneamento é resultado de bordas mais límpidas de albita.

O microclínio é geralmente pertítico e representado também por cristais parcialmente corroídos e euedrais, possuindo fraca extinção ondulante e geralmente apresentando inclusões de biotita, quartzo e plagioclásio. Na maioria das vezes, apresentam geminação em grade (Figura 7B) e encontra-se límpidos ou parcialmente sericitizados e caulinizados. Localmente, observa-se porções com grandes concentrações de fenocristais de feldspato potássico, ocasionando mudanças locais de composição da rocha.

Os minerais máficos são constituídos principalmente por biotita, secundado por hornblenda, representado 13 a $9 \%$ da rocha e ocorrem em meio a matriz félsica encontrandose dispersa caoticamente em placas isoladas (Figuras 7A e B) ou aglutinadas constituindo glúmeros micáceos (Figura 7C) e localmente estão inclusas nos feldspatos.

A biotita como máfico predominante encontra-se com uma distribuição aleatória e podem ser encontradas fortemente cloritizadas. O anfibólio é caracterizado por hornblenda e que no geral encontra-se fortemente biotitizada ou cloritizada. Essa transformação de hidratação resulta, às vezes, em quartzo + calcita microcristalina mas sendo o epidoto + biotita + clorita (Figura 7C) a paragêneses mais frequentes.

Os minerais acessórios como apatita, titanita, allanita, zircão e minerais opacos ocorrem em porcentagens muito pequenas e encontram-se distribuídas isoladamente ou associada aos minerais máficos. Os minerais secundários como sericita, epidoto, clorita e carbonatos, minerais opacos e hidróxidos de ferro são resultados saussuritização dos feldspatos e transformações dos minerais máficos.

\section{Unidade Ribeira}

As fácies róseas apresentam composição de monzogranito e variam principalmente pela quantidade de fenocristais presentes e pela textura fortemente porfirítica da fase inicial e que grada para termos levemente porfiríticos a inequigranulares para a fase final do stock rósea. Sugere-se para este corpo uma evolução das fácies róseas iniciais para as fácies róseas finais.

A distribuição de quartzo e minerais máficos (biotita e hornblenda) é muito pequena entre as fácies (Figura 6, Tabela 3), critério este que dificulta a distinção, mas com porcentagens maiores de quartzo e menores em minerais máficos em relação as fácies do batólito cinza. As texturas dominantes são a porfirítica serial, com uma redução das porcentagens de fenocristais até feições inequigranulares, variando entre 20 a $5 \%$ de fenocristais de feldspato potássico. Os fenocristais estão imersos em uma matriz de granulação media a grossa da fase inicial passando para média a fina nas fácies finais, apresentando texturas alotriomórfica à hipidiomórfica e de composição monzogranítica.

$\mathrm{O}$ quartzo é dominantemente intersticial definindo uma trama granítica (Figura 7D) e frequentemente apresentam extinção ondulante com a em intensidade variável de acordo com a anisotropia presente nestas rochas. $\mathrm{O}$ oligoclásio/andesina apresenta textura mirmequítica e geralmente intensamente zonado e está variação composicional é evidenciada 
principalmente pelo grau distintos de saussuritização do zoneamento. Muitas vezes, é resultado de bordas mais límpidas de albita.

O microclínio é geralmente pertítico e representado também por cristais parcialmente corroídos e euedrais, possuindo fraca extinção ondulante. Na maioria das vezes, apresentam geminação em grade (Figura 7B) e encontra-se límpidos ou parcialmente sericitizados $\mathrm{e}$ caulinizados.



Figura 7 - Fotomicrografias com polarizadores cruzados: A) Plagioclásio fortemente zonados; B) Microclínio com geminação cruzada; C) Núcleos de hornblenda aglutinadas e com fortes transformações para biotita + epidoto; D) Cristais de hornblenda e quartzo intersticiais; E) Microclínio pertítico e com geminação cruzada e carlsbad e entorno com recristalização de quartzo; F) Quartzo deformado com extinção ondulante. Legenda: Qtz: quartzo, Pl: plagioclásio, Mc: Microclínio; Ab: albita; Hbl: hornblenda; Bt: biotita; Ttn: titanita; Ep: epidoto; Ap: apatita. 
Os minerais máficos são constituídos principalmente por biotita, secundado por hornblenda, representado 7 a $9 \%$ da rocha e ocorrem em meio a matriz félsica, dispersa caoticamente em placas isoladas bem desenvolvidas (Figuras 7D) ou em consequência na redução de granulação das fácies mais tardia os (Figuras 7E e F), muitas das vezes dispondose na forma aglutinadas constituindo glúmeros micáceos.

A biotita como máfico predominante encontra-se com uma distribuição aleatória e podem ser encontradas fortemente cloritizadas.

O anfibólio é caracterizado por hornblenda e que no geral encontra-se fortemente biotitizada ou cloritizada. Essa transformação de hidratação resulta, às vezes, em quartzo + calcita microcristalina, mas sendo o epidoto + biotita + clorita a paragêneses mais frequentes. Este processo encontra-se nas fácies róseas intensificado pela anisotropia das rochas, visto na forma de recristalizações minerais nas bordas dos cristais de microclínio da figura $7 \mathrm{E}$ e, pela forte deformação e extinções ondulantes observadas na figura $7 \mathrm{~F}$.

Os minerais acessórios como apatita, titanita, allanita, zircão e minerais opacos ocorrem em porcentagens muito pequenas e encontram-se distribuídas isoladamente ou associada aos minerais máficos. Os minerais secundários como sericita, epidoto, clorita e carbonatos, minerais opacos e hidróxidos de ferro são resultados saussuritização dos feldspatos e transformações dos minerais máficos.

\section{LITOGEOQUÍMICA}

As análises geoquímicas realizadas nas rochas do Batólito Itaoca encontram-se enumeradas na tabela 3. As análises químicas foram realizadas no LABOGEO-IGCE/UNESP-Rio Claro, sendo utilizados Fluorescência de Raios $\mathrm{X}$ para os elementos maiores (concentração em \%), através de pastilha fundida em meio borato e para os elementos traços (ppm), através de pastilha prensada e ICP-AES para os elementos terras raras, segundo os padrões do laboratório (Malagutti et al., 1988).

A distribuição dos elementos maiores encontra-se caracterizado nos diagramas de Harker (1909) (Figuras 8A a H) e possibilita principalmente, quanto aos teores de sílica, definir as duas unidades de rochas, que já foram identificadas anteriormente: uma de composição intermediária, constituindo as fácies cinza, que apresentam valores de sílica entre 63 e $67 \%$ e que correspondem a intrusão inicial batolítica, constituída por quartzo monzonito (cinza 1) e variando com o acréscimo de sílica para monzogranito (cinza 3); e a outra, de rochas das fácies róseas que constituem num stock secundário, composto de monzogranito e caracterizado por rochas mais diferenciadas com valores $\mathrm{SiO}_{2}$ entre 70 a $71 \%$.

Para as rochas cinza menos diferenciadas da Unidade Itaoca os demais óxidos $\left(\mathrm{TiO}_{2}, \mathrm{Fe}_{2} \mathrm{O}_{3}\right.$, $\mathrm{MgO}, \mathrm{CaO}$ e $\mathrm{MnO}$ ), mostram correlação negativa em relação ao aumento em $\mathrm{SiO}_{2}$, evidenciando um empobrecimento destes em relação as rochas mais enriquecidas em sílica e empobrecimento em minerais máficos. As rochas róseas apresentam padrão similar as cinzas, somente mais enriquecidas em sílica. Observa-se a relação de uma redução gradual de $\mathrm{Fe}_{2} \mathrm{O}_{3}$, $\mathrm{MgO}, \mathrm{CaO}$ das fácies iniciais cinza para as fácies mais diferenciadas rósea, a partir da paragênese dos minerais máficos como hornblenda + biotita nos litotipos iniciais e a sua gradual redução para os termos ácidos.

As exceções ocorrem na distribuição dos álcalis, onde os teores de $\mathrm{Na}_{2} \mathrm{O}>3,8 \%$, oscilam num intervalo de variação mais ou menos constante, não apresentando grandes variações em relação ao teor em $\mathrm{SiO}_{2}$, com concentração de amostras de monzogranito, em torno de 4\%, enquanto que apresenta valores de $\mathrm{K}_{2} \mathrm{O}>5 \%$, valores estes que se encontra condizentes com as rochas graníticas diferenciadas.

Nos diagramas petrográficos de Le Maitre (1989) da figura 9A e de Middlemost (1985) da figura 9B, as amostras distribuem-se principalmente em dois campos, os das rochas intermediárias definidos por quartzo monzonito e pelas rochas ácidas constituído por granitos (monzogranito).

O diagrama Q-A-P de Le Maitre (1989) (Figura 9C) define para o conjunto principal de amostras cinza a composição quartzo monzonítica, com exceção da amostra que transiciona para monzogranito. As rochas da fácies rósea são caracterizadas como quartzo monzonito a fase inicial e monzogranito, a fase final.

O diagrama de séries magmáticas da figura 9D (Peacock, 1931) define uma tendência cálcio- 
alcalina e constitui um índice de que os pontos representativos das rochas aproximadamente 55 .

No diagrama de classificação petrográfica que utiliza os parâmetros multicatiônicos $\mathrm{Q}$ versus $\mathrm{P}$, de Debon et al. (1988) (Figura 9E), observa-se

estudadas são classificados dominantemente como quartzo monzonito a monzogranito com afinidade para as séries subalcalinas potássica a cálcio-alcalina.

Tabela 3. Resultado de análises químicas de amostras das rochas do Batólito Itaoca.

\begin{tabular}{|c|c|c|c|c|c|c|c|c|c|c|}
\hline \multicolumn{11}{|c|}{ Batólito Itaoca } \\
\hline & \multicolumn{3}{|c|}{ Unidade Itaoca } & \multicolumn{7}{|c|}{ Unidade Ribeira } \\
\hline & \multicolumn{3}{|c|}{ Fácies Cinza } & \multicolumn{7}{|c|}{ Fácies Róseo } \\
\hline & $1(\Delta)$ & $2(\Delta)$ & $3(\triangle)$ & $1(\square)$ & $1(\square)$ & $2(\square)$ & $2(\square)$ & $3(\square)$ & $3(\square)$ & $3(\square)$ \\
\hline $\mathrm{SiO}_{2}$ & 63.84 & 64.69 & 67.44 & 67.2 & 67.38 & 65.58 & 66.16 & 70.8 & 70.15 & 71.17 \\
\hline $\mathrm{TiO}_{2}$ & 0.96 & 0.89 & 0.65 & 0.61 & 0.7 & 0.76 & 0.7 & 0.47 & 0.39 & 0.4 \\
\hline $\mathrm{Al}_{2} \mathrm{O}_{3}$ & 14.99 & 15.11 & 14.54 & 13.59 & 13.66 & 13.79 & 13.96 & 13.69 & 13.69 & 13.72 \\
\hline $\mathrm{Fe}_{2} \mathrm{O}_{3}$ & 4.7 & 4.43 & 3.49 & 3.37 & 3.61 & 3.89 & 3.76 & 2.39 & 2.17 & 2.08 \\
\hline MnO & 0.06 & 0.06 & 0.05 & 0.05 & 0.05 & 0.7 & 0.06 & 0.03 & 0.03 & 0.06 \\
\hline MgO & 0.93 & 0.81 & 0.54 & 0.8 & 0.8 & 1.07 & 0.94 & 0.38 & 0.35 & 0.37 \\
\hline $\mathrm{CaO}$ & 3.33 & 3.18 & 2.52 & 2.41 & 2.52 & 3.2 & 2.69 & 2 & 2.07 & 1.68 \\
\hline $\mathrm{Na}_{2} \mathrm{O}$ & 4.21 & 4.38 & 4.09 & 4.16 & 4.05 & 4.26 & 4.26 & 3.94 & 4.2 & 3.81 \\
\hline $\mathrm{K}_{2} \mathrm{O}$ & 5.36 & 5.02 & 5.76 & 5.67 & 5.92 & 5.89 & 5.93 & 5.74 & 5.42 & 5.91 \\
\hline $\mathrm{P}_{2} \mathrm{O}_{5}$ & 1.15 & 0.88 & 0.49 & 0.87 & 0.8 & 1.03 & 1.11 & 0.23 & 0.47 & 0.3 \\
\hline LOI & 0.57 & 1.06 & 0.52 & 1.3 & 0.44 & 0.49 & 0.45 & 0.4 & 0.49 & 0.54 \\
\hline Total & 100.04 & 100 & 100.01 & 100.02 & 100.01 & 100.04 & 100.02 & 100.06 & 100.01 & 100.01 \\
\hline $\mathrm{Cr}$ & 17 & 18 & 5 & 18 & 12 & 19 & 28 & 6 & 9 & 27 \\
\hline $\mathrm{Cu}$ & 7 & $<3$ & 3 & 7 & 7 & 6 & $<3$ & $<3$ & 13 & 8 \\
\hline $\mathrm{Ni}$ & 13 & 13 & 15 & 27 & 11 & 37 & 33 & 14 & 15 & 29 \\
\hline Zn & 70 & 30 & 45 & 57 & 59 & 69 & 58 & 39 & 79 & 59 \\
\hline $\mathbf{B a}$ & 2129 & 1800 & 2024 & 1957 & 1784 & 2385 & 2461 & 1744 & 2630 & 2177 \\
\hline $\mathbf{R b}$ & 135 & 128 & 130 & 142 & 120 & 145 & 151 & 120 & 154 & 136 \\
\hline $\mathbf{S r}$ & 1167 & 831 & 742 & 891 & 952 & 1041 & 1114 & 903 & 1378 & 899 \\
\hline $\mathbf{Z r}$ & 38 & 66 & 42 & 28 & 31 & 28 & 33 & 56 & 43 & 21 \\
\hline $\mathbf{Y}$ & 10 & 4 & 5 & 10 & 5 & 22 & 12 & 6 & 11 & 9 \\
\hline $\mathbf{N b}$ & 16 & 12 & 20 & 10 & 16 & 18 & 19 & 13 & 12 & 21 \\
\hline La & 98.7 & 62.2 & 70.2 & 78.5 & 85.3 & 156.8 & 101.9 & 68.4 & 106.7 & 87 \\
\hline $\mathrm{Ce}$ & 175.8 & 112 & 106.5 & 147.6 & 143.3 & 185.1 & 185.6 & 144 & 188.3 & 166.9 \\
\hline Nd & 69 & 42.8 & 36.2 & 57.6 & 52.2 & 113.8 & 70.6 & 52.2 & 73.1 & 66.7 \\
\hline Sm & 10.8 & 6.3 & 5.4 & 9.2 & 7.9 & 18.1 & 11.3 & 8.1 & 11.5 & 10.7 \\
\hline $\mathbf{E u}$ & 2.48 & 1.5 & 1.32 & 2.15 & 1.86 & 4.37 & 2.63 & 1.8 & 2.6 & 2.45 \\
\hline Gd & 6.53 & 3.77 & 3.39 & 5.71 & 4.88 & 12.27 & 6.92 & 4.58 & 6.92 & 6.58 \\
\hline Dy & 3.59 & 1.8 & 2.03 & 3.26 & 2.6 & 6.45 & 3.95 & 2.27 & 3.75 & 3.62 \\
\hline Er & 1.43 & 0.72 & 0.9 & 1.41 & 1.1 & 2.68 & 1.67 & 0.92 & 1.49 & 1.6 \\
\hline $\mathbf{Y b}$ & 1.1 & 0.5 & 0.8 & 1.2 & 0.9 & 1.8 & 1.3 & 0.7 & 1.1 & 1.2 \\
\hline $\mathbf{L u}$ & 0.12 & 0.05 & 0.08 & 0.13 & 0.08 & 0.22 & 0.17 & 0.07 & 0.12 & 0.15 \\
\hline$[\mathbf{L a} / \mathbf{Y b}] \mathbf{N}$ & 60.49 & 83.87 & 59.16 & 44.10 & 63.90 & 58.73 & 52.85 & 65.88 & 65.40 & 48.88 \\
\hline Eu* & 40.30 & 23.43 & 20.39 & 34.61 & 29.68 & 70.10 & 42.33 & 29.61 & 42.85 & 40.14 \\
\hline $\mathrm{Eu} / \mathbf{E u} *$ & 0.50 & 0.52 & 0.52 & 0.50 & 0.51 & 0.51 & 0.50 & 0.49 & 0.49 & 0.49 \\
\hline $\mathrm{Ce} / \mathrm{Sm}$ & 3.93 & 4.29 & 4.76 & 3.87 & 4.38 & 2.47 & 3.96 & 4.29 & 3.95 & 3.76 \\
\hline Gd/Yb & 4.79 & 6.08 & 3.42 & 3.84 & 4.38 & 5.50 & 4.30 & 5.28 & 5.08 & 4.42 \\
\hline
\end{tabular}

No diagrama de classificação com relação ao teor em potássio de Taylor (1976) (Figura 9F), observa-se que as amostras se distribuem na transição do campo da série cálcio-alcalina alto potássio, sendo um grande número das amostras pertencentes à série shoshonítica, definido pelo forte enriquecimento em potássio dos litotipos analisados. Nos diagramas de alumínio saturação, as rochas são classificadas segundo a figura 9G (Maniar \& Picolli, 1989), como granitóides peraluminosos em razão da presença dominante de biotita.

O diagrama de Debon \& Le Fort (1983) (Figura 9H) define para a sequência magmática a predominância granitos com clinopiroxênio + anfibólio + biotita. 

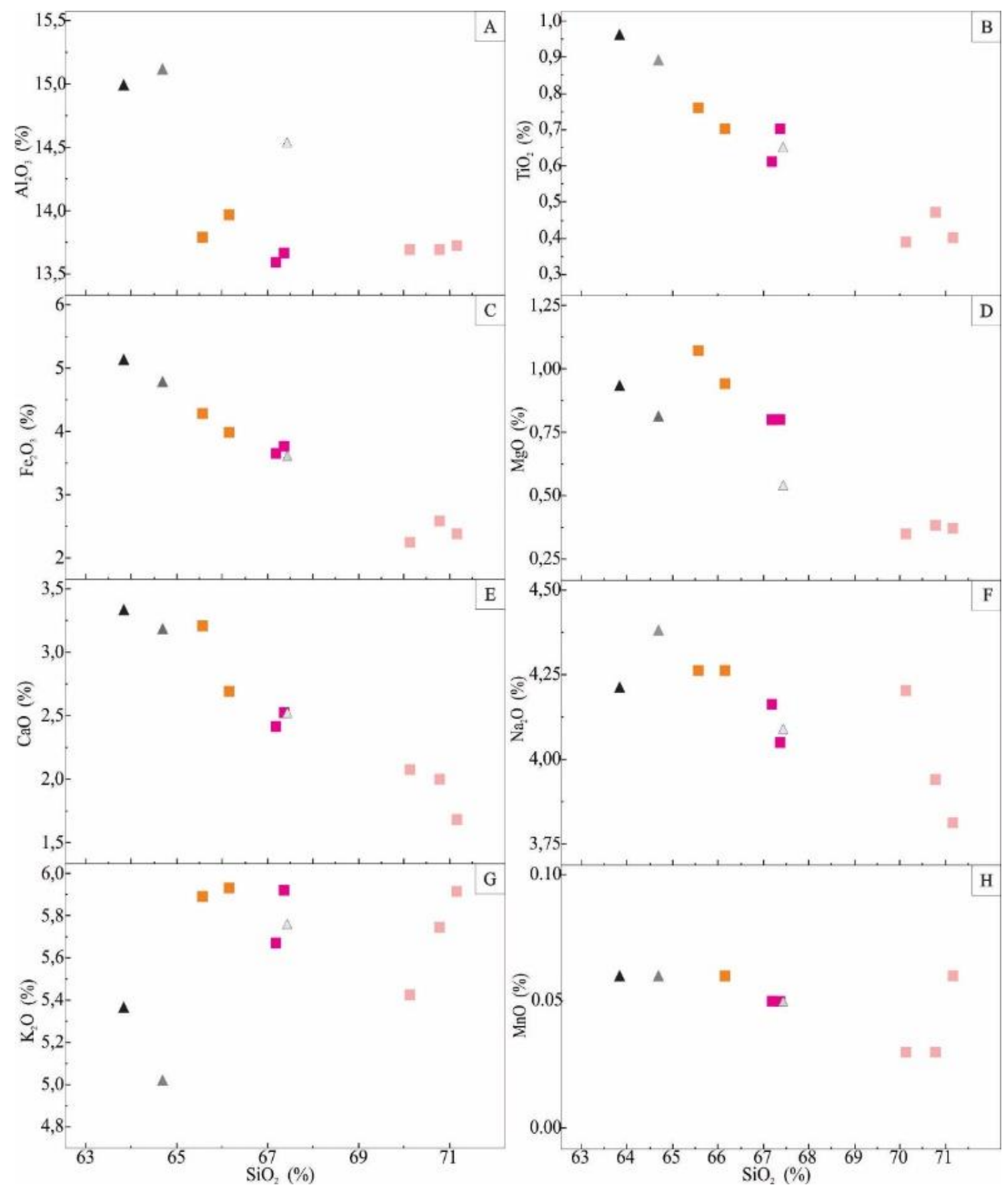

Figura 8 - Diagramas geoquímicos de variação para elementos maiores tipo Harker (1909) das amostras de rochas do Batólito Itaoca.

Quanto à distribuição dos elementos traços dos diagramas binários da figura $10 \mathrm{~A}$ à $\mathrm{F}$, observa-se que a distribuição no diagrama $\mathrm{Rb}$ versus $\mathrm{SiO}_{2}$ (Figura 10A), apresenta uma correlação positiva com o incremento da sílica e potássio nos litotipos. A correlação positiva deve-se principalmente às rochas com a alta porcentagem de biotita, além de expressivos valores de feldspato potássico.

No geral, o rubídio substitui o potássio do feldspato potássico e, secundariamente, o potássio, na biotita. Em relação ao estrôncio, no diagrama $\mathrm{Sr}$ versus $\mathrm{SiO}_{2}$ (Figura 10B), os litotipos mostram baixos valores e um decaimento em um trend em relação ao aumento da $\mathrm{SiO}_{2}$.

No geral, o estrôncio apresenta correlação direta com cálcio, evidenciado na redução de plagioclásios para as rochas mais diferenciadas e enriquecidas em $\mathrm{SiO}_{2}$.

Portanto, sugere-se um processo de fracionamento magmático, envolvendo principalmente os feldspatos, com consequente aumento de feldspato potássico a partir da segregação e redução em plagioclásios e, consequente empobrecimento de $\mathrm{Sr}$ do líquido magmático, disponível para as fases mais diferenciadas. 

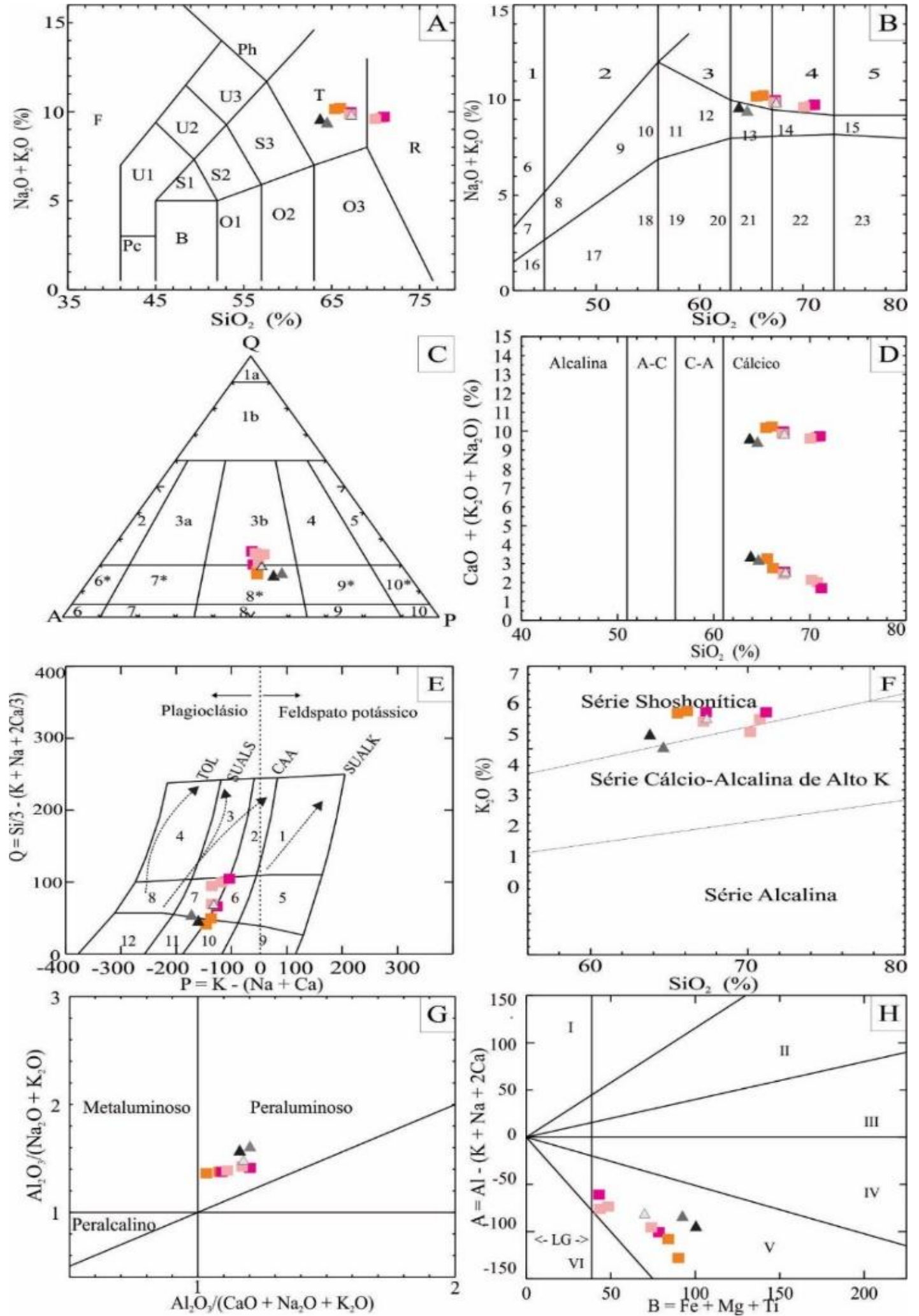

Figura 9 - Diagramas geoquímicos de classificação das amostras de rochas do Batólito Itaoca. Legenda: A) Le Maitre (1989) (R-granito; T-quartzo monzonito), B) Middlemost (1985) (13- quartzo monzonito;14-monzogranito); C) Le Maitre (1989) (3b monzogranito; 8* quartzo monzonito), D) Peacock (1931), E) Q x P de (Debon et al., 1988) 6-quartzo monzonito, 7- quartzo monzodiorito, Abr.: TOL=toleítica, CAA=cálcico-alcalina, SUBALS= subalcalina sódica, SUBALK= subalcalina potássica, F) Taylor (1976), G) Índice de Shand de Maniar \& Picolli (1989) e H) Debon \& Le Fort (1983) campo V- granitos peraluminosos com clinopiroxênio + anfibólio + biotita.

A porcentagem de bário, no diagrama $\mathrm{Ba}$ versus $\mathrm{SiO}_{2}$ (Figura 10C) apresenta uma leve redução dos valores e é admitida sua associação mais facilmente aos plagioclásios.
A correlação negativa com o aumento de sílica é evidenciada pela redução de plagioclásio para as rochas mais diferenciadas.

Os valores de zircônio no diagrama $\mathrm{Zr}$ versus 
$\mathrm{SiO}_{2}$ (Figura 10D) mostra uma correlação negativa para as fácies mais diferenciadas. $\mathrm{O}$ decréscimo do $\mathrm{Zr}$ indica forte fracionamento ao longo da evolução dos líquidos e sua diminuição nas concentrações nos líquidos mais diferenciados finais, sugere-se o fracionamento simultâneo de titanomagnetita, ilmenita e zircão

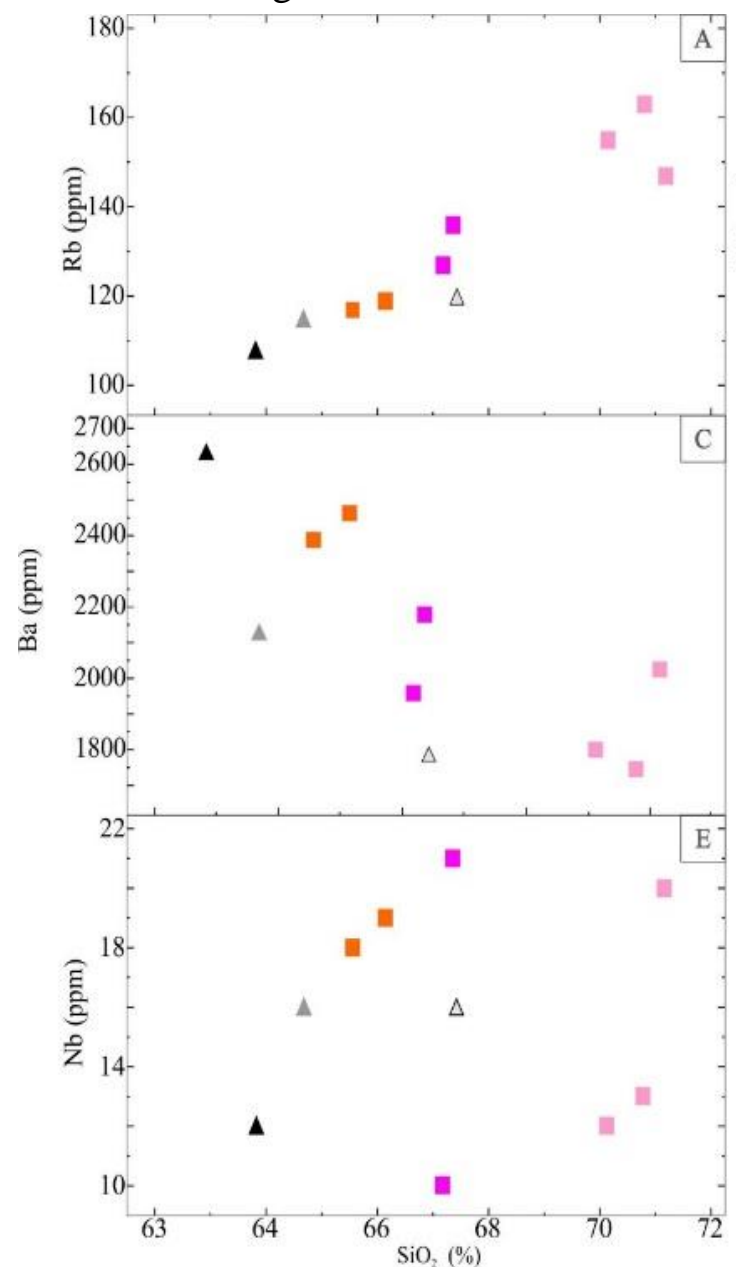

no processo evolutivo do líquido residual magmático.

Os valores de nióbio (Figura 10E) mostram uma leve correlação positiva para as fácies mais diferenciadas e o Y versus $\mathrm{SiO}_{2}$ (Figura 10F) mostra uma leve distribuição negativa para as fácies mais diferenciadas.

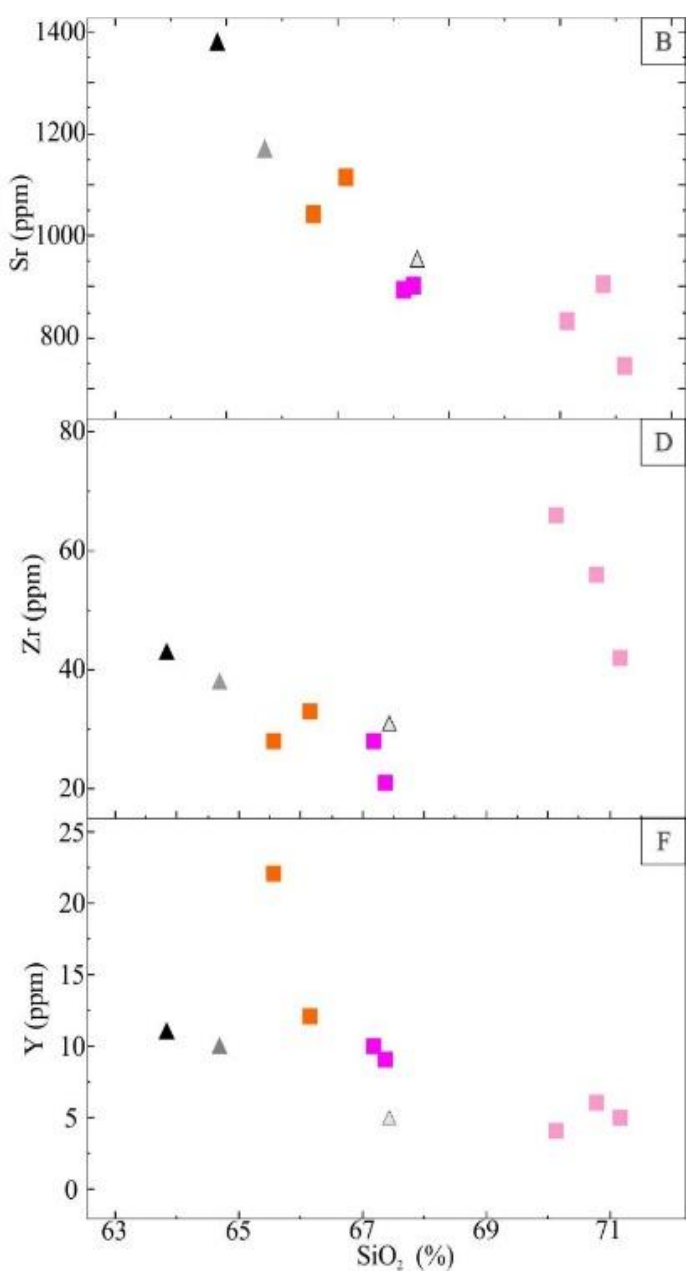

Figura 10. Diagramas geoquímicos binários para elementos traços para as amostras de rochas da Batólito Itaoca.

No diagrama ternário de El Bouseily \& El Sokkary (1975) (Figura 11A), observa-se um agrupamento das rochas classificadas como quartzo diorito pouco diferenciados para granitos normais. Nos diagramas de caracterização de ambiente geotectônico observa-se nas figuras 11B e C (Pearce et al., 1984), que as rochas são classificadas como pertencentes a uma suíte magmática de granitos sin- a tardi- colisionais de arco magmático.

No diagrama da figura 11D (Batchelor \& Bowden, 1985), as amostras encontram-se distribuídas entre os campos dominantemente sin- a tardi- orogênicos de ambiente de arco magmático. No diagrama (Figura 11E) de Whalen et al. (1987), o resultado obtido reforça a assinatura de granitos apresentando médias composicionais para granitos dos tipos $\mathrm{S}, \mathrm{M}$ e I
(SMI), condizentes com as características mineralógicas e geoquímicas de granito do tipo I

No diagrama da figura $11 \mathrm{~F}$ (Frost et al., 2001), as amostras encontram com padrões geoquímicos que transicionam entre granitos do tipo A "ferroan" e aos granitos com afinidades de granitos magnesianos do tipo I cordilheranos de ambiente de arco magmático.

Nos variogramas de multielementos os elementos traços foram normalizados para os valores de meteoritos condríticos de Thompson (1982) (Figura 12A) e apresenta um forte empobrecimento em $\mathrm{Nb}$ e $\mathrm{Zr}$ e para os valores de crosta inferior de Weaver \& Tarney (1984) (Figura 12B) mostra um forte empobrecimento $\mathrm{Rb}, \mathrm{Ba}, \mathrm{Zr}$ e leve em $\mathrm{Sr}$ e Ti. O empobrecimento nestes elementos indica tratar-se de um conjunto de rochas com padrão de arco magmático e 
pouco diferenciadas no geral.

Os diagramas de elementos terras raras (ETR) foram normalizadas segundo os valores de meteoritos condríticos de Boynton (1984) (Figura 12C) e segundo os valores para crosta inferior Weaver \& Tarney (1984) (Figura 12D). Os padrões gerais de distribuições de ETR obtidos apresentam distribuição assimétrica, paralela e similar, o que evidencia amostras distintas e cogenéticas, com valores crescentes de ETR, para as rochas mais diferenciadas, mas passíveis de distinção e sugerindo evolução das
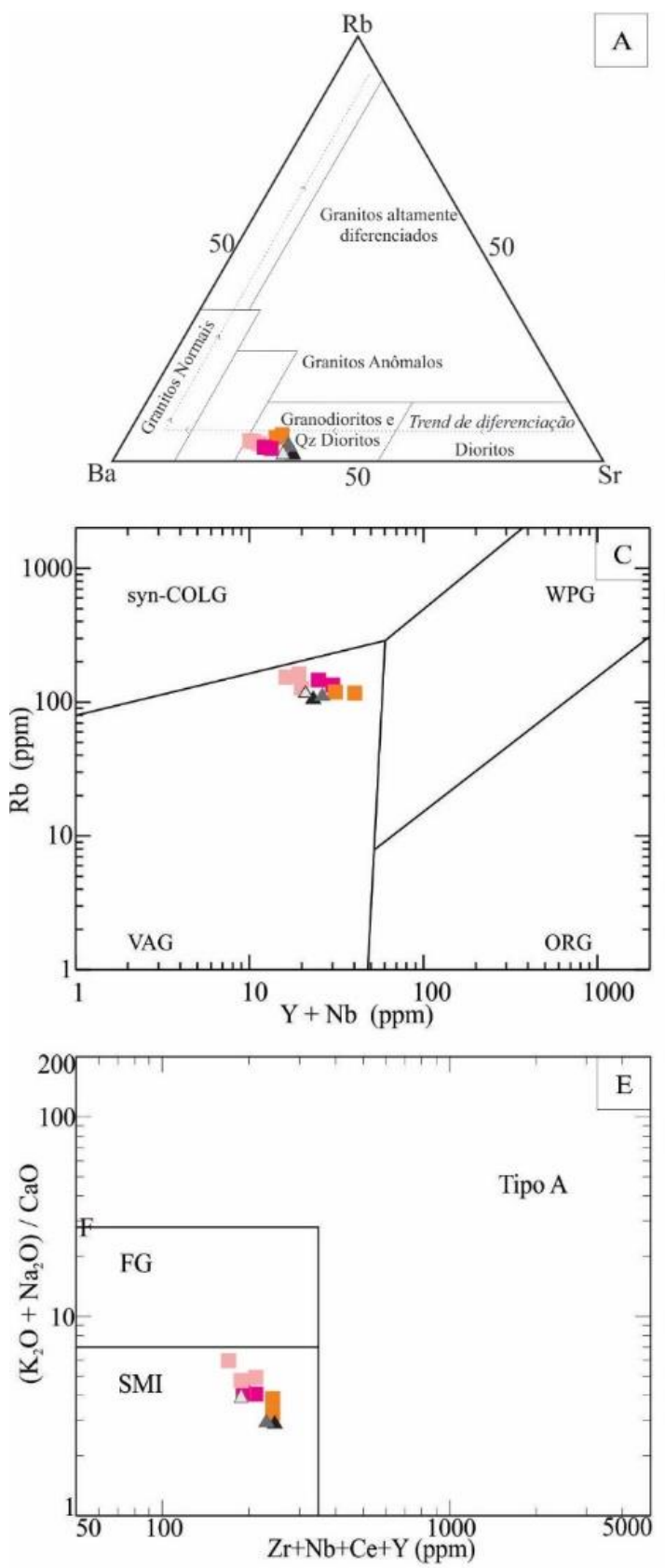

rochas analisadas por processo de fracionamento magmático.

O padrão geral de distribuição dos elementos terras raras (ETR) normalizados pelo condrito (Boynton, 1984) apresentam para as fácies cinza a média de $[\mathrm{La} / \mathrm{Yb}=60,78]_{\mathrm{N}}$ em relação aos valores da fácies rósea $[\mathrm{La} / \mathrm{Yb}=57,10]_{\mathrm{N}}$ o que reflete a similaridade dos padrões. A anomalia negativa de Eu é fraca a ausente, com $\left[\mathrm{Eu} / \mathrm{Eu}^{*}=0,50\right]_{\mathrm{N}}$, sugere fraca a partir do fracionamento de plagioclásio e feldspato potássico no processo de diferenciação.
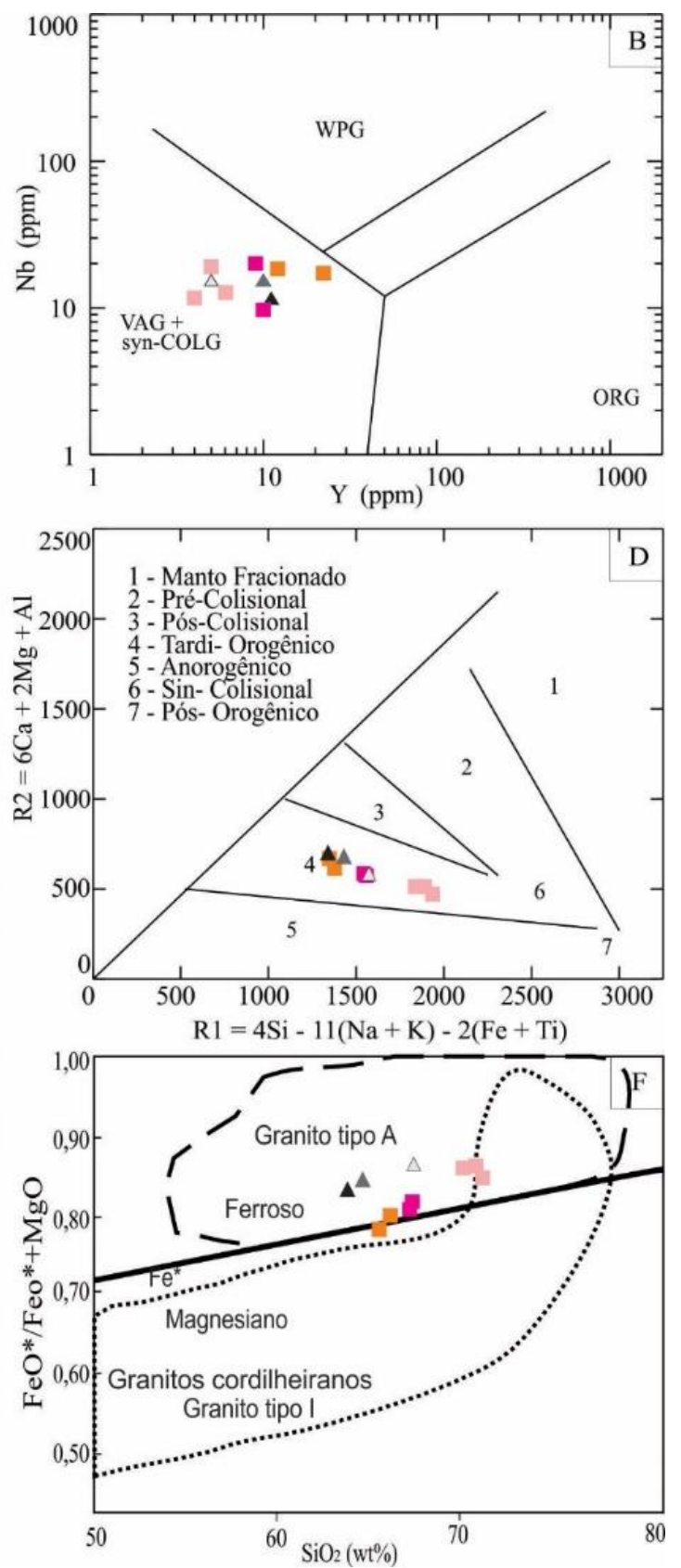

Figura 11 - Diagramas geoquímicos de classificação de ambientes tectônicos para as amostras de rochas do Batólito Itaoca. Legenda: A) Diagrama ternário de El Bouseily e El Sokkary (1975); B e C) Pearce et al. (1984) (Syn-COLG)granitoide sin-colisional; (VAG)-granitoide de arco vulcânico; (WPG-granitoide intraplaca, (ORG)-Granitóides de Cadeias Oceânicas. D) Batchelor \& Bowden (1985). E) Whalen et al. (1987) diagrama apresentando os campos de granitos anorogênicos (Tipo A), granitos félsicos fracionados (FG) e médias composicionais dos granitos dos tipos $\mathrm{S}, \mathrm{M}$ e I (SMI). F) Frost et al. (2001), diagramas de caracterização de plútons "ferroan" e magnesianos. 



Figura 12. Diagramas de variogramas de multielementos incompatíveis e elementos de terra raras para as amostras de rochas do Batólito Itaoca. Legenda: Elementos incompatíveis normalizados. A) Valores para meteoritos condríticos de Thompson (1982) e B) Valores da crosta inferior de Weaver \& Tarney (1984). Elementos terras raras, C) Valores dos meteoritos condríticos de Boynton (1984) e D) Valores da crosta inferior de Weaver \& Tarney (1984).

\section{CONCLUSÕES}

A área envolve rochas da sequência metavulcanossedimentar do Supergrupo Açungui de idade meso- a neoproterozoica e são compostas por litotipos do Grupo Lajeado, mais especificadamente as formações Betari, Bairro da Serra, Água Suja, Mina de Furnas, Mármore Apiaí, Serra da Boa Vista e Passa Vinte, além do Gabro Apiaí, Complexo Três Córregos e por rochas básicas, correlacionadas a Formação Serra Geral e rochas sedimentares da Bacia do Paraná.

O Batólito Itaoca é um corpo intrusivo de forma aproximadamente circular, de $200 \mathrm{Km}^{2}$, com direção geral NE-SW e constituído principalmente por -biotita-hornblenda-quartzo monzonito a monzogranito, holo- a leucocráticos. Possuem dominantemente textura porfirítica a raramente inequigranular, com fenocristais de dimensões inferiores a 3 a $4 \mathrm{~cm}$, granulação média a grossa, coloração cinza ou rósea e isotrópica a sub-orientada com discreta foliação de baixo ângulo e alto ângulo milonítico e ou cataclástico.

Nas áreas marginais é observada uma redução na dimensão dos fenocristais, associada a resfriamento rápido. As fácies tardias comuns são constituídas de diques equigranulares de cor cinza, aplitos róseos e cinza e veios pegmatíticos.

As rochas do batólito foram individualizadas em três unidades, as de colorações cinza denominada de Unidade Itaoca e as de coloração rósea denominada de Unidade Ribeira, além de uma Associação Indiferenciadas. A Unidade Itaoca foi subdividida em 3 fácies de composição quartzo monzonito cinza a monzogranito cinza e foram denominadas de fácies 1,2 e 3 e a Unidade Ribeira de composição monzogranito rósea e denominada de fácies 1,2 e 3 .

O arranjo deformacional-metamórfico é identificado principalmente nas rochas epimetamórficas do Supergrupo Açungui e apresenta uma evolução estrutural marcada por três deformações principais, atribuídas ao evento neoproterozoico.

Os dois eventos iniciais são relacionados a uma tectônica progressiva e tangenciais $\mathrm{D}_{1} / \mathrm{D}_{2}$, ligados à fase colisional, sendo identificado duas fases iniciais de baixo ângulo e a colocação e deformação das rochas sin-tardi colisionais do Batólito Itaoca, que apresentam localmente a imposição de uma foliação de baixo ângulo, possivelmente remetendo ao final da fase $\mathrm{D}_{2}$.

Associado ao final da fase tectônica dúctil $\mathrm{D}_{2}$, ocorre a colocação e deformação das rochas sin- 
colisionais do Batólito Itaoca vista, principalmente, na reorientação dos minerais máficos (biotita e hornblenda) e a geração de porfiroblastos nas auréolas de metamorfismo de contato desenvolvidas lateralmente aos corpos ígneos. A deformação posterior é marcada por uma tectônica transcorrente/transpressiva em que ocorre associada à ascensão magmática tardia e a atual estruturação alongada, com trend preferencial NE, dos granitos pós-colisionais de caráter dúctil-rúptil e retrometamórfica, associadas às bordas do corpo magmático.

O metamorfismo regional progressivo é do tipo Barroviano, com rochas em fácies xisto verde alto a anfibolito baixo, com ocorrências locais de metamorfismo de contato e o dinâmico que apresentam natureza retrometamórfica. As deformações registradas na área são facilmente observadas nas rochas metassedimentares pertencentes ao Grupo Lajeado.

$\mathrm{O}$ metamorfismo regional $\mathrm{M}_{1}$, está relacionado aos principais eventos deformacionais $\mathrm{D}_{1}$ e $\mathrm{D}_{2}$. O emplacement ígneo, associado ao evento metamórfico $\mathrm{M}_{2}$, está relacionado às rochas granitoides do Batólito Itaoca que recristaliza os minerais das rochas encaixantes alcançando fácies albita $\mathrm{e}$ hornblenda hornfels e definindo o metamorfismo
$\mathrm{M}_{2}$ ) Durante $\mathrm{o}$ evento deformacional $\mathrm{D}_{3}$, evidenciado na área pelas zonas de cisalhamento que balizam o batolítico a norte e sul, tem-se o evento metamórfico $\mathrm{M}_{3}$ associado, que é representado, na área, por metamorfismo dinâmico e rochas miloníticas a fortemente orientadas, principalmente na porção sul do corpo. $\mathrm{O}$ evento metamórfico $\mathrm{M}_{3}$, por sua vez, é característico pelas paragêneses retrometamórficas.

A partir das análises petrográficas e geoquímica das unidades, foi possível observar que, possivelmente, a Unidade Itaoca trata do corpo principal dominante cinza, caracterizado por um fracionamento magmático de quartzo monzonito inicial, evoluindo para monzogranito. As fases róseas da Unidade Ribeira evoluem principalmente com o enriquecimento de quarto das fácies menos evoluídas para as finais de composição monzogranítica.

Geoquimicamente, trata-se de um granito cálcio alcalino peraluminoso, sin a tardi colisional, pertencem à série de alto potássio a shoshonítica, similares a granitos "ferroan", apresentando assinatura de granito do tipo I cordilheirano gerados pela fusão da crosta inferior e associado à evolução de Arco Magmático.

\section{AGRADECIMENTOS}

Os autores agradecem ao apoio do CNPq (proc. $\mathrm{n}^{\mathrm{o}}$ : 304614/2017-3).

\section{REFERENCIAS}

ALGARTE, J.P.; MARTINS, A.J.M.; MORGENTAL, A.; DAITX, E.C.; ANDRADE Jr, F.S.; BATOLLA Jr, F.; FERREIRA, F.J.F.; PINTO, G.G.; CUNHA, H.C.S.; DRUMOND, J.B.V., RODRIGUES, J.C.; YAMAMOTO, K.; KAEFER, L.Q.; CHIEREGATI, L.A.; PINHO FILHO, W.D.; ADDAS, W. Projeto Sudeste do Estado de São Paulo. Relatório Final. São Paulo: DNPM/CPRM, 1973.

ALMEIDA, F.F.M. Novas ocorrências de fósseis no PréCambriano brasileiro. Anais da Academia Brasileira de Ciências, v. 29, n. 1, p. 63-72, 1957.

ALMEIDA, F.F.M. \& HASUI, Y. O Pré-Cambriano do Brasil. São Paulo, Blücher, 378 p., 1984.

ALMEIDA, F.F.M. Origem e evolução da plataforma brasileira. Rio de Janeiro: DNPM/DGM. Boletim 241, 36 p., 1967.

ALMEIDA, F.F.M.; HASUI, Y.; PONÇANO, W.L.; DANTAS, A.S.L.; CARNEIRO, C.D.R.; MELO, M.S.; BISTRICH, C.A. Mapa Geológico do estado de São Paulo em escala 1: 500.000. Nota explicativa. São Paulo, IPT, Monografias 6, v. 1, 126 p., 1981.

ALMEIDA, F.F.M.; HASUI, Y., BRITO-NEVES, B.B.; FUCK, R.A. Províncias estruturais brasileiras. SIMPÓSIO GEOLOGIA NORDESTE, 8, 1977, Campina Grande. Anais... Campina Grande: Sociedade Brasileira de Geologia, p. 363391,1977

BISTRICHI, C.A.; CARNEIRO, C.D.R.; DANTAS, A.S.L.; PONÇANO, W.L.; CAMPANHA, G.A.C.; NAGATA, N.; ALMEIDA, M.A.; STEIN, D.P.; MELO, M.S.; CREMINI, O.A. Mapa Geológico do Estado de São Paulo em 1: 500.000.
IPT/Pró-Minério, São Paulo, v. 2, 1981

BATCHELOR, R.A. \& BOWDEN, P. Petrogenetic interpretation of granitic rock series using multicationic parameters. Chemical Geology, v. 48, p. 43-55, 1985.

BOIN, M.N.; MELLO, I.S.C.; SILVA, J.R.B. Geoquímica dos granitoides de Itaoca (SP). In: Simpósio Regional de Geologia, 4, 1983, São Paulo. Anais...São Paulo: Sociedade Brasileira de Geologia, p. 313-326, 1983.

BOYNTON, W.V. Geochemistry of the rare earth elements: meteorite studies. In: HENDERSEN, P. (Coords). Rare earth element geochemistry. Elsevier Amsterdam, p. 63-114, 1984. CAMPANHA, G.A.C. Tectônica Proterozoica no Alto e Médio Vale do Ribeira, Estados de São Paulo e Paraná. São Paulo, 1991. 296p. Tese (Doutorado), Instituto de GeociênciasUniversidade de São Paulo.

CAMPANHA, G.A.C. O papel do sistema de zonas de cisalhamento transcorrentes na configuração da porção meridional da Faixa Ribeira. São Paulo, 2002, 105p. Tese (Livre Docência), Instituto de Geociências - Universidade de São Paulo.

CAMPANHA, G.A.C. \& SADOWSKI, G.R. Tectonics of the southern portion of the Ribeira Belt (Apiaí Domain). Precambrian Research, v. 98, p. 31-51, 1999

CAMPANHA, G.A.C.; BISTRICHI, C.A.; ALMEIDA, M.A. Considerações sobre a organização litoestratigráfica e evolução tectônica da faixa de dobramentos Apiaí. In: SIMPÓSIO SULBRASILEIRO DE GEOLOGIA, 3, 1987, Curitiba. Atas.. Curitiba: Sociedade Brasileira de Geologia, v. 2, p. 725-742. 
CAMPANHA, G.A.C.; GIMENEZ FILHO, A.; CAETANO, S.L.V.; PIRES, F.A.; DANTAS, A.S.L.; TEIXEIRA, A.L.; DEHIRA, L.K. Geologia das folhas Iporanga (SG-22-X-B-V2) e Gruta do Diabo (SG-22-X-B-VI-1), Estado de São Paulo. São Paulo: PROMINÉRIO / IPT, Relatório 22.352, 1985.

CAMPANHA, G.A.C.; GIMENEZ FILHO, A.; CAETANO, S.L.V.; PIRES, F.A.; DANTAS, A.S.L.; TEIXEIRA, A.L.; DEHIRA, L.K. Geologia e estratigrafia da região das folhas Iporanga e Gruta do Diabo, Vale do Ribeira, São Paulo. In: CONGRESSO BRASILEIRO DE GEOLOGIA, 34, Goiânia, 1986. Anais...Goiânia: Sociedade Brasileira de Geologia, 1986. CAMPANHA, G.A.C.; BASEI, M.A.S; TASSINARI, C.C.G.; NUTMAN, A.P.; FALEIROS, F.M. Constraining the age of the Iporanga Formation with shrimp U-Pb zircon: implications for possible ediacaran glaciation in the Ribeira belt, SE Brazil. Gondwana Research, v. 13, p. 117-125, 2008.

CAMPANHA, G.A.C.; FALEIROS, F.M.; BASEI, M.A.S.; TASSINARI, C.C.G.; NUTMAN, A.P.; VASCONCELOS, P.M. Geochemistry and age of mafic rocks from the Votuverava Group, southern Ribeira Belt, Brazil: Evidence for $1490 \mathrm{Ma}$ oceanic back-arc magmatism. Precambrian Research, v. 266 , p. 530-550, 2015.

CHIODI FILHO, C.; SANTOS, J.F.; SOARES, P.C.; MORETZJOHN, J.S. Estudo de elementos terras raras para caracterização e avaliação metalogenética de granitoides no escudo paranaense. In: CONGRESSO BRASILEIRO DE GEOQUÍMICA, Il, Rio de Janeiro, 1989. Anais...Rio de Janeiro: Sociedade Brasileira de Geologia, p. 487-498, 1989.

CORDANI, U.G.; DELHAL, J.; LEDENT, O. Orogenèses superposeés dans le Précambrien du Brésil sud-oriental (États du Rio de Janeiro et de Minas Gerais). Revista Brasileira de Geociências, v. 3, n. 1, p. 1-22, 1973.

CORDANI, U.G.; SATO, K.; TEIXEIRA, W.; TASSINARI, C.C.G.; BASEI, M.A.S. Crustal evolution of the South American platform. In: CORDANI, U.G.; MILANI, E.J.; THOMAZ FILHO, A.; CAMPOS, D.A. (Eds.) Tectonic evolution of South America, Rio de Janeiro, p. 19- 40, 2000.

CURY, L.F.; SIGA JR., O.; HARARA, O.M.M.; PRAZERES FILHO, H.J.; BASEI, M.A.S. Aspectos tectônicos das intrusões dos granitos do Cerne, Passa Três e Rio Abaixo, sudeste do PréCambriano paranaense. Estudo baseado em datações 39Ar40Ar em micas. Revista do Instituto de Geociências, v. 8, n. 1, p. 87-104, 2008.

DEBON, F. \& LE FORT, P. A chemical-mineralogical classification of common plutonic rocks and associations. Transactions of the Royal Society of Edinburgh Earth Sciences, v. 73, p. 135-149, 1983.

DEBON, F., LE FORT, P., SABATÉ, P. Uma classificação químico-mineralógica das rochas plutônicas comuns e suas associações, método e aplicações. Revista Brasileira de Geociências. v. 18, n. 2, p. 122-133, 1988.

El BOUSEILY, A.M. \& El SOKKARY, A.A. The Relation between $\mathrm{Rb}, \mathrm{Ba}$ and $\mathrm{Sr}$ in Granitic Rocks. Chemical Geology, v. 16, p. 207-219, 1975.

ENS, Y.H. Petrogênese dos escarnitos de Itaoca-Vale do Ribeira -SP. São Paulo, 1990, 172 p. Dissertação (Mestrado), Instituto de Geociências, Universidade de São Paulo.

FALEIROS, F.M. Zona de Cisalhamento Ribeira: deformação, metamorfismo e termobarometria de veios sintectônicos. 2003. Tese de Doutorado. Universidade de São Paulo. FALEIROS, F.M. Evolução de Terrenos TectonoMetamórficos da Serrania do Ribeira e Planalto do Alto Turvo (SP, PR). São Paulo, 2008. 306 p. Tese (Doutorado), Instituto de Geociências - Universidade de São Paulo.

FALEIROS, F.M.; CAMPANHA, G.A.C.; BELLO, R.M.S.; FUZIKAWA, K. Quartz recrystallization regimes, c-axis texture transitions and fluid inclusion re-equilibration in a prograde green schist to amphibolite facies mylonitic zone (Ribeira Shear Zone, SE Brazil). Tectonophysics, v. 485, p. 193-214, 2010.
FALEIROS, F.M.; FERRARI, V.C.; COSTA, V.S.; CAMPANHA, G.A.C. Geoquímica e petrogênese de metabasítos do grupo Votuverava (Terreno Apiaí, Cinturão Ribeira Meridional): evidências de uma bacia retro arco caliminiana. Geologia USP, Série Científica, v. 11, n. 2, p. 135-155, 2011.

FALEIROS, F.M.; MORAIS, S M.; CROSTA, V.S. Geologia e Recursos minerais da Folha Apiaí - SG.22-X-B-V, Estados de São Paulo e Paraná, Escala 1:100.000 - São Paulo: CPRM, 107p. 2012.

FIORI, A.P. Tectônica e estratigrafia do Grupo Açungui a norte de Curitiba. São Paulo, 1990. 261 p. Tese (Livre Docência). Instituto de Geociências, Universidade de São Paulo, 1990.

FIORI, A.P. Tectônica e estratigrafia do Grupo Açungui, PR. Boletim IG-USP. Série Científica, v. 23, p. 55-74, 1992.

FIORI, A.P. Evolução geológica da bacia Açungui. Boletim Paranaense de Geociências, v. 42, p. 7-27, 1994.

FROST, B.R.; BARNES, C.G.; COLLINS, W.J.; ARCULUS, R.J.; ELLIS, D.J.; FROST, C.D. A geochemical classification for granitic rocks. Journal of Petrology, v. 40, p. 261-293, 2001.

FUCK, R.A.; MARINI, O.J.; TREIN, E. Contribuição ao estudo das rochas graníticas do Estado do Paraná. Boletim Paranaense de Geociências, v. 23, p. 25, 1967.

FUCK, R.A.; MARINI, O.J.; TREIN, E.; MURATORI, A. Geologia do Leste Paranaense. In: CONGRESSO BRASILEIRO DE GEOLOGIA, 25, São Paulo, 197I. Anais... São Paulo, Sociedade Brasileira de Geologia, 1971, v. 1, p. 122130.

GOMES, C.B.; ARRUDA, J.R.; BERENHOLC, M.; HYPÓLITO, R. Geoquímica de maciços graníticos da região do Ribeira. Parte I; elementos traços. Anais da Academia de Ciências e Letras, v. 47, p. 113-130, 1975a.

GOMES, C.B.; ARRUDA, J.R.; BERENHOLC, M.; HYPÓLITO, R. Geoquímica de maciços graníticos da região do Ribeira. Parte II; elementos traços. Anais da Academia de Ciências e Letras, v. 47, p. 459-476, 1975 b.

HARKER, A. The Natural History of Igneous Rocks. London, Methuen, 384p., 1909.

HASUI, Y. A grande Colisão Pré-Cambriana do Sudeste brasileiro e a Estruturação Regional. São Paulo, UNESP, Geociências, v. 29, n. 2, p. 141-169, 2010.

HASUI, Y. Sistema Orogênico Mantiqueira. In: HASUI, Y., CARNEIRO, C.D.R., ALMEIDA, F.F.M.A., BARTORELLI, A. (org.) Geologia do Brasil. São Paulo, Beca, p. 331-372, 2012.

HASUI, Y. \& OLIVEIRA, M.A.F. Província Mantiqueira. Setor Central. In: ALMEIDA, F.F. \& HASUI, Y. (Eds). O Précambriano do Brasil. São Paulo, p. 308-344, 1984.

HASUI, Y.; CARNEIRO, C.D.R.; BISTRICHI, C.A. Os Granitos e Granitóides da Região de Dobramentos Sudeste nos Estados de São Paulo e Paraná. In: CONGRESSO BRASILEIRO DE GEOLOGIA, 30, 1978, Recife. Anais...Recife: Sociedade Brasileira de Geologia, 1978, p. 2579-2593.

HASUI, Y; DANTAS, A.S.L; CARNEIRO, C.D.R; BISTRICH, C.A. O embasamento Pré-Cambriano e Eo-Paleozoico em São Paulo. Mapa Geológico do Estado de São Paulo, Escala 1.500.000. São Paulo, SP, Brasil, v. 1, p. 12-45, 1981.

HEILBRON, M.; PEDROSA-SOARES, A.C.; CAMPOS NETO, M.C.; SILVA, L.C. TROUW, R.A.J.; JANASI, V.A. Província Mantiqueira. In: MANTESSO NETO, V.; BARTORELLI, A.; CARNEIRO, C.D.R.; BRITO-NEVES, B.B. (Eds.). Geologia do Continente Sul-americano. São Paulo: Ed. Beca, p. 203236, 2004.

INSTITUTO GEOGRÁFIC0 GEOLÓGIC0 (IG). Mapa Geológico do Estado de São Paulo, em 1:1.000,000. São Paulo, 1974

INSTITUTO GEOGRÁFICO GEOLÓGICO (IG). Mapa geológico do Estado de São Paulo, em 1: 1.000 .000 , São Paulo, 1963. 
JANASI, V.A. \& ULBRICH, H.H.G.J. Inventário Bibliográfico de Granitos do Estado de São Paulo. Boletim Instituto de Geociências. Publicação Especial, v. 11, 253p. 1992.

LANDIM, P.M.B.; GOMES, C.B.; ARRUDA, J.R.; FÚLFARO, V.J. Análise de agrupamentos aplicada ao estudo geoquímico do granito Itaoca. In: CONGRESSO BRASILEIRO DE GEOLOGIA, 28, 1974, Porto Alegre. Anais... Porto Alegre: Sociedade Brasileira de Geologia, 1974, v. 7, p. 161-168.

LE MAITRE, R.W. Classification of Igneous Rocks and Glossary of Terms. Recommendations of the International Union of Geological-Sciences Subcommission on the Systematics of Igneous Rocks. Blackwell, Oxford, 193p. 1989

LOPES, A.P.; RIBEIRO, L.M.A.L.; SALVADOR, E.D.; PAVAN, M.; SILVA, A.D.R. Informe de Recursos Minerais, Série Províncias Minerais do Brasil. Programa Geologia do Brasil. São Paulo: CPRM,158 p., 2017.

MALAGUTTI, M.I.A.; BAHIA FILHO, O.; MORENO, M.M.T.; NARDY, A.J.R. Determinação de elementos terras raras e ítrio em rochas silicáticas por ICP-AES com separação em resina trocadora de íons. Geochimica Brasiliensis, v. 12, n. 1/2, p. 75 80, 1998 .

MANIAR, P.D. \& PICOLLI, P.M. Tectonic Discrimination of Granitoids. Geological Society of America Bulletin, v. 101, p. 635-643, 1989.

MELCHER, G.C. Contribuição ao conhecimento do Distrito Mineral do Ribeira de Iguapé, Estados de São Paulo e Paraná. 1965. Tese (Livre-Docência). Escola Politécnica, Universidade de São Paulo.

MELCHER, G.C. \& JOHNSON, R.F. Geologia e depósitos minerais do vale do rio Ribeira de Iguape. Divisão de Fomento da Produção Mineral, n. 98/99, 1956.

MELCHER, G.C.; CORDANI, U.G.; DAMASCENO, E.C.; GIRARDT, V.A.V.; GOMES, C.B., LELLI, S.H.S.; MELFI, A.J. Geologia das Rochas Pré-Cambrianas do Vale do Rio Ribeira de Iguape. In: CONGRESSO BRASILEIRO DE GEOLOGIA, 25, 1971, São Paulo. Boletim de Resumos...São Paulo: Sociedade Brasileira de Geologia, 1971a, p. 193.

MELCHER, G.C.; CORDANI, U.G.; DAMASCENO, E.C.; GIRARDT, V.A.V.; GOMES, C.B., LELLI, S.H.S.; MELFI, A.J. Geologia da Folha de Apiaí, SP e PR. In: CONGRESSO BRASILEIRO DE GEOLOGIA, 25, 1971, São Paulo. Boletim de Resumos...São Paulo: Sociedade Brasileira de Geologia, 1971b p. 194.

MELCHER, G.C.; GOMES, C.B.; CORDANI, U.G.; BETTENCOURT, J.S.; DAMACENO, E.C.; GIRARDI, V.A.V.; MELFI, A.J. Geologia e petrologia das rochas metamórficas e graníticas associadas do Vale do Rio Ribeira de Iguape, SP e PR. Revista Brasileira de Geologia, v. 3, n. 2, p. 97-123, 1973.

MELFI, A.J.; CORDANI, U.G.; BITTENCOURT, I. Reconhecimento fotogeológico de parte do Grupo Açungui. Bragantia, v. 24, n. 34, p. 447-474, 1965.

MELLO, I.S.C. Geologia e aspectos metalogenéticos do Maciço Itaoca, Vale do Ribeira, SP e PR. São Paulo. 1995. 167p. Tese (Doutorado) - Instituto de Geociências, Universidade de São Paulo.

MELLO, I.S.C. \& BETTENCOURT, J.S. Geologia e aspectos metalogenéticos do batólito Itaoca, Vale do Ribeira (São Paulo e PR). In: CONGRESSO BRASILEIRO DE GEOLOGIA, 37 , 1992, São Paulo. Anais...São Paulo: Sociedade Brasileira de Geologia, v. 2, p. 209, 1992

MELLO, I.S.C. \& BETTENCOURT, J.S. Geologia e gênese das mineralizações associadas ao Maciço Itaoca, Vale do Ribeira, SP e PR. Brazilian Journal of Geology, v. 28, n. 3, p. 257-268, 1998.

MELLO, I.S.C. \& SILVA, R.B. Mineralizações associadas aos granitóides de Itaoca (SP). In: CONGRESSO BRASILEIRO DE GEOLOGIA, 33, Rio de Janeiro, 1984. Anais... Rio de Janeiro: Sociedade Brasileira de Geologia, 1984, v. 6, p. 3001 3011.

MELLO, I.S.C.; SILVA, J.R.B.; BOIN, M.N.; SARAGIOTTO,
A.J.R.; SILVA, R.B. Geologia dos granitóides de Itaoca (SP). In: SIMPÓSIO REGIONAL DE GEOLOGIA, 3, Curitiba, 1981. Atas... Curitiba: Sociedade Brasileira de Geologia, v. 1, p. 82-93, 1981.

MELLO, I.S.C.; SILVA, R.B.; GORAIEB, C.L. As mineralizações de tungstênio (scheelita) nos granitóides de Itaoca (SP). In: SIMPÓSIO REGIONAL DE GEOLOGIA, 5, São Paulo, 1985. Atas... Rio São Paulo: Sociedade Brasileira de Geologia, v. 2, p. 433-444, 1985.

MIDDLEMOST, E.A.K. Naming materials in the magma/igneous rock system. Earth-Sciences Reviews 37: 215 224. 1985 .

MORGENTAL, A.; BATTOLA JÚNIOR, F.; PINTO, G.G.; PAIVA, I.P.; DRUMOND, J.B.V. Projeto Sudelpa: Relatório final. São Paulo. SUDELPA/CPRM. 18v., 1975.

MORGENTAL, A.; BATTTOLA JUNIOR, F; PINTO, G.G.; PAIVA, I.P.; DRUMOND, J.B.V. Projeto Geoquímica no Vale da Ribeira, convênio DNPM/CPRM, 8 v., 1978

PEACOCK, M.A. Classification of igneous rocks series. Journal Geology, v. 39, p. 54-67, 1931.

PEARCE, J.A.; HARRIS N. B.W.; TINDLE A.G. Trace Element Discrimination Diagrams for the Tectonic Interpretation of Granitic Rocks. Journal of Petrology, v. 25, p. 956-983, 1984. PERROTTA, M.M.; SALVADOR, E.D.; LOPES, R.C.; D'AGOSTINHO, L.Z.; PERUFFO, N.; GOMES, S.D.; SACHS, L.L.; MEIRA, V.T.; GARCIA, M.G.M.; LACERDA FILHO, J.V. Mapa Geológico do Estado de São Paulo, escala 1:750.000. Programa Geologia do Brasil-PGB, CPRM, São Paulo, 2005.

PETRI, S. \& SUGUIO, K. Sobre os metassedimentos do grupo Açungui do extremo sul do estado de São Paulo. São Paulo. Secretaria de Serviços e Obras Públicas/Faculdade de Filosofia, Ciências e Letras da USP, p. 1-98, 1969.

SALAZAR, C.A.; ARCHANJO, C.J.; BABINSKI, M.; LIU, D. Magnetic fabric and zircon $\mathrm{U}-\mathrm{Pb}$ geochronology of the Itaoca pluton: implications for the Brasiliano deformation of the southern Ribeira belt (SE Brazil). J. S. Am Earth Sci, v. 26, p. 286-299, 2008

SANTOS, T.M.B.; TASSINARI, C.C.G; FONSECA, P.E. Diachronic collision, slab break-off and long-term high thermal flux in the Brasiliano-Pan-African orogeny: Implications for the geodynamic evolution of the Mantiqueira Province. Precambrian Research, v. 260, p. 1-22, 2015

SILVA, A.T.S.F. Mapa Geológico, Folha Apiaí (SG.22-X-B-V) escala 1:100.000, (com nota explicativa). In: SILVA, A.T.S.F.: FRANCISCONI, O.; GODOY, A.M; BATOLLA JR, F. Projeto Integração e Detalhe Geológico no Vale do Ribeira. Relatório Final. São Paulo, DNPN/CPRM, 1981.

STRECKEISEN, A.L. Plutonic rocks: classification and nomenclature recommended by the IUGS Subcommission on the systematics of igneous rocks. Geotimes, n. 18, p. 26-30, 1976

TASSINARI, C.C.G. \& MELLO, I.S.C. A idade e a origem das mineralizações do granitoide de Itaoca. In: CONGRESSO BRASILEIRO DE GEOLOGIA, 38, Camboriú, 1994. Anais... Camboriú: Sociedade Brasileira de Geologia, 1994, p. 304.

TASSINARI, C.C.G.; MELLO, I.S.C.; GOMES, D.P. Sr and Pb isotope evidence for the on gen of skarn, sulfides and fluor mineralizations of the Itaoca granitoid, southern Brazil. In: INTERNATIONAL CONFERENCE ON GEOCHRONOLOGY, COSMOCHRONOLOGY AND ISOTOPE GEOLOGY, 8. Berkeley, 1994. Abstracts... Berkeley: USGS, 1994. p. 316.

TAYLOR, W.P. Intrusion and differentiation of granitic magma at high level in the crust: the Puscao Pluton. Lima, Peru. Journal of Petrology, p. 82-133, 1976.

THOMPSON, R.N. British Tertiary volcanic province. Journal of Geology, v. 18, p. 49-107, 1982.

VLACH, S.R.F.; JANASI, V.A.; VASCONCELLOS, A.C.B.C. The Itú Belt: associated calc alkaline and aluminous a-type late Brasiliano granitoids in the states of São Paulo and Paraná, 
southern Brazil. In: CONGRESSO BRASILEIRA DE GEOLOGIA, 36, 1990, Natal. Anais...Natal: Sociedade Brasileira de Geologia, v. 4, p. 1700-1711, 1990.

WEAVER, B. \& TARNEY, J. Empirical approach to estimating the composition of the continental crust. Nature, v. 310, p. 57557, 1984.

WERNICK, E. Aspectos petrológicos dos granitóides da Província Ribeira, SP e PR. In: SIMPÓSIO REGIONAL DE GEOLOGIA, 2, Rio Claro, 1979. Anais...Rio Claro: Sociedade Brasileira de Geologia, v. 1, p. 101-116, 1979.

WERNICK, E. \& GOMES, C.B. Geoquímica de Maciços Graníticos da Região do Ribeira. Parte III: Considerações Petrológicas. Anais da Academia de Ciências e Letras, v. 49, p. $157-169,1977$.

WERNICK, E. \& GOMES, C.B. Granitos e metamorfismo no vale do rio Ribeira de Iguape, SP e PR. In: CONGRESSO BRASILEIRO DE GEOLOGIA, 28, 1974, Porto Alegre. Anais... Porto Alegre: Sociedade Brasileira de Geologia, v. 5, p. $145-154,1974$

WHALEN, J. W.; CURRIE, K. L.; CHAPPEL, B. W. A-Type Granites: Geochemical Characteristics, Discrimination and Petrogenesis. Contributions to Mineralogy and Petrology, v. 95, p. 407-419, 1987.
ZANELLA, R.R.; BERTON, F.; RAMOS, V.L.; CURY, L.F. Fases de deformação associadas à zona de cisalhamento Ribeira na região de Adrianópolis - PR. In: CONGRESSO BRASILEIRO DE GEOLOGIA, 47, 2014, Salvador. Anais... Salvador: Sociedade Brasileira de Geologia, 2014, p. 1214.

ZANELLA, R.R.; BERTON, F., RAMOS, V.L.; CURY, L.F. Contribuições à Análise Estrutural da borda sul do Granito Itaoca, Vale do Ribeira - PR e SP. In: XV SIMPÓSIO NACIONAL DE ESTUDOS TECTÔNICOS IX INTERNATIONAL SYMPOSIUM ON TECTONICS, 2015, Vitória. Anais...Vitória: Sociedade Brasileira de Geologia, 2015.
Submetido em 14 de fevereiro de 2020 Aceito em 15 de maio de 2020 